\title{
EFEITO DE EXTRATOS AQUOSOS DE MELIÁCEAS SOBRE Bemisia tabaci (GENNADIUS, 1889) BIÓTIPO B (HEMIPTERA: ALEYRODIDAE) EM TOMATEIRO
}

\author{
ANTONIO PANCRÁCIO DE SOUZA \\ Biólogo
}

Orientador: Prof. Dr. JOSÉ DJAIR VENDRAMIM

Dissertação apresentada à Escola Superior de Agricultura "Luiz de Queiroz", Universidade de São Paulo, para obtenção do título de Mestre em ciências, Área de Concentração: Entomologia.

PIRACICABA

Estado de São Paulo - Brasil

Setembro - 1999 
Dados Internacionais de Catalogação na Publicação (CIP) DIVISĀo DE BIBLIOTECA E DOCUMENTAÇĀO - Campus "Luiz de Queiroz"/USP

\section{Souza, Antonio Pancrácio de}

Efeito de extratos aquosos de Meliáceas sobre Bernisia tabaci(Gennadius, 1889) biótipo B (Hemiptera: Aleyrodidae) em tomateiro / Antonio Pancrácio de Souza. - - Piracicaba, 1999.

92 p. : il.

Dissertaçāo (mestrado) - Escola Superior de Agricultura Luiz de Queiroz, 1999. Bibliografia.

1. Meliácea 2. Mosca-branca 3. Praga agricola 4. Tomate I. Título 


\section{AGRADEÇO}

A Deus, pelo amor Dele que me sustentou até aqui com saúde e alegria.

\section{OFEREÇO}

aos meus pais, João Pancrácio de Souza e Elza de Souza,

e aos meus irmãos Pancrácio (In memorian), Oribes, Gilberto e Magno.

\section{DEDICO}

À Luciane Julião dos Santos, minha companheira de todos os momentos,

Nisto conhecemos o amor, em que Cristo deu a sua vida por nós; e devemos dar nossa vida pelos irmãos.

I João, capítulo 3; versículo 16. 


\section{AGRADECIMENTOS}

Ao Prof. Dr. José Djair Vendramim, pela excelente orientação, amizade e equilíbrio, características que me trouxeram refrigério para seguir em frente.

Ao Prof. Dr. Celso Omoto pela revisão do "Summary".

Ao Dr. José Raul Valério, pela orientação, incentivo e amizade, durante o meu período de bolsista de iniciação científica e aperfeiçoamento científico pelo CNPq.

À Marilene, Valdomiro, Adão, Cláudio, Valéria, pelo companheirismo que tem caracterizado nossa amizade.

Aos colegas Maria Teresa, Ariane, Rogério, Vargas, Reginaldo, Fábio, Henrique, Paulo, Edilene e Sônia, pela amizade e convivência sempre animada no setor.

À Coordenadoria de Aperfeiçoamento de Pessoal de Nível Superior (CAPES), pela concessão de bolsa de estudos.

Aos colegas de curso cuja amizade e companheirismo sempre levarei comigo.

Aos professores do Departamento, pelo incentivo, dedicação no ensino e exemplo de qualidade profissional associados com a amizade e respeito aos alunos.

Aos funcionários do setor, pela força que me deram, seja em trabalho ou amizade.

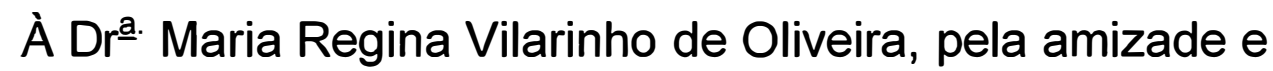
identificação dos insetos. 
Ao Dr. André Luiz Lourenção pela ajuda no inicio da colônia de mosca branca, bem como pela sua amizade que surgiu de nossos contatos.

Aos amigos da República, pela boa amizade e incentivo.

Aos irmãos em Cristo que carrego em meu coração desde Campo Grande, juntamente com aqueles que conheci em Piracicaba.

E a todos aqueles que participaram em alguma etapa desse processo, que, embora não mencionados certamente serão recompensados pelo nosso Deus que tem presenteado cada um deles. 


\section{SUMÁRIO}

Página

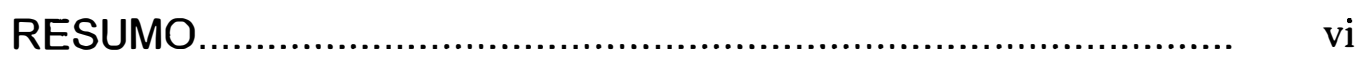

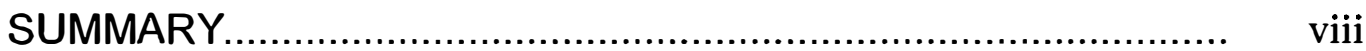

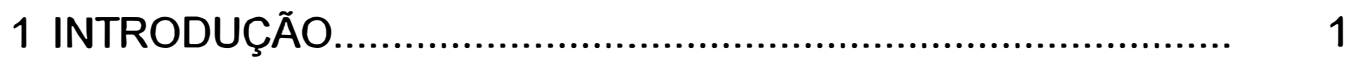

2 REVISÃO DE LITERATURA..................................................... 4

2.1 Considerações gerais sobre Bemisia spp.............................. 4

2.1.1 Aspectos taxonômicos......................................................... 4

2.1.2 Distribuição geográfica e plantas hospedeiras...................... 7

2.1.3 Aspectos morfológicos e ecológicos..................................... 9

2.1.4 Aspectos biológicos de B. tabaci biótipo B........................... 12

2.2 Extratos botânicos............................................................. 15

2.2.1 Considerações gerais....................................................... 15

2.2.2 Azadirachta indica Juss................................................... 17

2.2.3 Efeito de extratos botânicos sobre Bemisia spp.................... 19

2.2.4 Efeito de extratos de meliáceas sobre outros insetos sugadores fitófagos.................................................................... 25

3 MATERIAIS E MÉTODOS..................................................... 29

3.1 Manutenção da criação estoque de B. tabaci.......................... 29

3.2 Obtenção e manutenção das plantas de tomateiro................... 29

3.3 Coleta e preparo dos extratos vegetais.................................. 30

3.4 Determinação da concentração adequada de extratos aquosos de $M$. azedarach e de $T$. pallida para estudos de bioatividade em relação a $B$. tabaci biótipo $B$............................... $\quad 30$

3.5 Seleção das estruturas vegetais de $M$. azedarach e de $T$. pallida mais efetivas, na forma de extrato aquoso, em relação a B. tabaci biótipo B 
3.6 Efeitos de extratos aquosos de três meliáceas sobre a biologia de $B$. tabaci biótipo B ….............................................. 33

4 RESULTADOS E DISCUSSÃO................................................

4.1 Determinação da concentração adequada de extratos aquosos de Melia azedarach e de Trichilia pallida para estudos de bioatividade em relação a Bemisia tabaci biótipo $B$

4.1.1 Primeiro experimento

4.1.2 Segundo experimento.

36

4.2 Seleção das estruturas vegetais de $M$. azedarach e de $T$. pallida mais efetivas, na forma de extrato aquoso, em relação a B. tabaci biótipo B

4.2.1 Experimentos com M. azedarach ...................................... 44

4.2.2 Experimentos com T. pallida ........................................ 50

4.3 Efeito de extratos aquosos de três meliáceas sobre a biologia de B. tabaci biótipo $B$

56

4.3.1 Primeiro experimento........................................................ 56

4.3.2 Segundo experimento ...................................................... 57

4.4 Considerações finais................................................................ 64

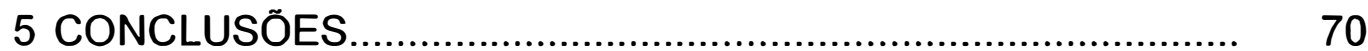

REFERÊNCIAS BIBLIOGRÁFICAS............................................ 71 


\title{
EFEITO DE EXTRATOS AQUOSOS DE MELIÁCEAS SOBRE A MOSCA BRANCA Bemisia tabaci (GENNADIUS, 1889) BIÓTIPO B EM TOMATEIRO
}

\author{
Autor: ANTONIO PANCRÁCIO DE SOUZA \\ Orientador: Prof. JOSÉ DJAIR VENDRAMIM
}

\section{RESUMO}

Com o objetivo de determinar a bioatividade de extratos aquosos de três plantas meliáceas, Melia azedarach L., Trichilia pallida Swartz e Azadirachta indica A. Juss, em relação à mosca branca Bemisia tabaci (Gennadius, 1889) biótipo B, criada em tomateiro, foram avaliados alguns parâmetros biológicos do inseto, tratado nas fases de ovo e ninfa com os referidos extratos. Inicialmente, foram testados extratos aquosos de folhas de $M$. azedarach e ramos de $T$. pallida, nas concentrações de 1,2 e $3 \%(p / v)$, visando obter a concentração mais adequada para avaliação do efeito dessas meliáceas sobre a mosca branca. Com base na avaliação da mortalidade e duração das fases de ovo e ninfa, foi selecionada a concentração de $3 \%$. A seguir, utilizando-se extratos a $3 \%$, foram comparados os frutos verdes, frutos maduros, folhas e ramos de $M$. azedarach e os ramos, folhas e córtex de $T$. pallida, em experimentos independentes para cada planta. Os extratos foram aplicados sobre os ovos e sobre os ovos e ninfas com idade de 3 dias, avaliando-se a mortalidade e duração das fases de ovo e ninfa. Os frutos verdes foram a estrutura mais efetiva de $M$. azedarach, vindo a seguir as folhas, frutos maduros e ramos, enquanto que, para $T$. pallida, a maior eficiência foi obtida com ramos seguindo-se as folhas; o extrato de córtex não apresentou bioatividade. Finalmente, os extratos de frutos verdes de $M$. azedarach e de ramos de $T$. pallida foram comparados com o extrato de sementes de $A$. indica, 
todos a $3 \%$, sendo a aplicação feita sobre ovos e ninfas (três dias) e apenas sobre ninfas, avaliando-se a mortalidade e duração da fase imatura, a fecundidade e a longevidade dos adultos. Constatou-se que o extrato de $T$. pallida apresentou ação ovicida superior aos outros dois extratos enquanto o extrato de $A$. indica foi o mais eficiente em relação às ninfas. Concluiu-se ainda que os extratos aplicados sobre ovos não atuam sobre as ninfas; que os extratos aplicados sobre sobre ovos e ninfas não afetam a duração da fase imatura e que não há efeito dos extratos aplicados sobre ninfas na fecundidade e longevidade dos adultos. 


\section{EFFECT OF AQUEOUS EXTRACTS OF MELIACEAE PLANTS ON SILVERLEAF WHITEFLY Bemisia tabaci (GENNADIUS, 1889) BIOTYPE B IN TOMATOES}

Autor: ANTONIO PANCRÁCIO DE SOUZA Orientador: Prof. JOSÉ DJAIR VENDRAMIM

\section{SUMMARY}

The objective of this research was to determinate the bioactivity of aqueous extracts of three Meliaceae plants (Melia azedarach, Trichilia pallida and Azadirachta indica) on silverleaf whitefly Bemisia tabaci (Gennadius) biotype $B$ reared on tomato plants, evaluating some biological parameters of the insect. The extracts were applied on eggs and nymphs. Firstly, aqueous extracts of $M$. azedarach leaves and $T$. pallida twigs were tested at concentrations of 1, 2 and $3 \%$ to select an adequate one to evaluate the activity of these plants on the insect. Based on mortality and duration of the egg and nymphal stages, it was selected the concentration of $3 \%$. Then, using the extracts at $3 \%$ the activities of $M$. azedarach fresh fruits, rape fruits, leaves and twigs and T. pallida twigs, leaves and cortex were evaluated. Each plant was tested in a separate experiment. The extracts were applied on eggs and on eggs and nymphs of 3days old. The evaluation consisted on the mortality and duration of egg and nymphal stages. $M$. azedarach fresh fruits were the most effective extract, followed by the leaves, rape fruits and twigs. For T. pallida, the twigs have better activity than the leaves. The cortex did not show activity on whiteflies. Finally, $M$. azedarach fresh fruit and $T$. pallida twig extracts were compared with $A$. indica seed extract. The extracts was applied at concentration of $3 \%$ on eggs and nymphs (3-days old) and only on nymphs. The following parameters were evaluated: mortality and duration of the immature phase and fecundity and 
longevity of the adults. T. pallida extract showed the highest ovicidal activity. A. indica extract was more effective on nymphs than the other extracts. The extracts applied on eggs did not affect the nymphs. The extracts applied on eggs and nymphs did not affect the duration of immature stage. When the extracts were applied on nymphs no effect on fecundity and longevity of the adults were observed. 


\section{INTRODUÇÃO}

A mosca branca Bemisia tabaci (Gennadius, 1889) atualmente é considerada uma das principais pragas do tomateiro. Seus danos são causados diretamente pela sucção da seiva, injeção de toxinas e liberação de "honeydew" na superfície das folhas, levando à formação de fumagina, e indiretamente pela transmissão de doenças viróticas (Ohnesorge \& Rapp, 1986 e Yokomi et al., 1990). Com o surgimento do biótipo $B$, considerado por alguns taxonomistas como uma nova espécie, Bemisia argentifolii Bellows \& Perring, os danos têm sido intensificados em função da maior agressividade desse novo biótipo, que resulta da sua maior fecundidade, ampla gama de hospedeiros, alta resistência aos inseticidas e capacidade de causar desordens fisiológicas nas plantas (Costa \& Brown, 1990; De Barro, 1995 e Yokomi et al., 1990).

No Brasil, os surtos de $B$. tabaci em hortaliças e ornamentais intensificaram-se, a partir de 1991, nos municípios de Paulinia, Holambra, Jaguariúna e Arthur Nogueira, Estado de São Paulo, destacando-se, entre as culturas mais atacadas, o tomate, berinjela e abóbora, observando-se sempre, associados ao ataque, os sintomas inerentes ao biótipo $B$, principalmente 0 prateamento das folhas em abóbora, amarelecimento irregular dos frutos em tomateiro e queda drástica da produção (Lourenção \& Nagai, 1994). Exemplares de mosca branca coletados em tomateiro no Distrito Federal foram identificados pela Dra. Judith Brown, da Universidade do Arizona (EUA) como sendo do biótipo B, confirmando, assim, a presença desse biótipo no Brasil 
(França et al., 1996). Atualmente, o referido biótipo encontra-se disseminado desde o Paraná até o Rio Grande do Norte, em importantes regiões produtoras, provocando prejuizos em várias culturas, destacando-se, o tomate, abóbora, melão, berinjela, brócolos, mandioca, melancia, feijão e pimentão, além de plantas ornamentais e silvestres (Villas Bôas, 1997).

O controle desse inseto, nas diversas regiões em que ele tem provocado danos econômicos, tem sido feito quase que exclusivamente através de inseticidas organossintéticos e tratos culturais. Prabhaker et al. (1985) mencionaram, por outro lado, que características biológicas e comportamentais de $B$. tabaci como o rápido desenvolvimento, elevada fecundidade e grande capacidade de dispersão são fatores que aumentam a probabilidade de aparecimento de resistência aos inseticidas. Por isso, vários autores têm recomendado o uso de inseticidas de diferentes grupos químicos como uma estratégia para reduzir a velocidade de desenvolvimento da resistência (Castle et al., 1996; Dittrich et al., 1990; Horowitz et al., 1988 e Prabhaker et al., 1988).

Em razão desse fato e dos outros problemas causados pelos inseticidas no agroecossistema, como a contaminação do ambiente e a diminuição da população de inimigos naturais, métodos alternativos aos inseticidas sintéticos têm sido estudados para o controle da mosca branca. Dentre esses métodos, inclui-se o uso de extratos botânicos, alguns dos quais têm apresentado resultados satisfatórios para controle dessa praga, em condições de laboratório, porém exigindo altas dosagens para emprego no campo (Flint \& Parks, 1989 e Leskovar \& Boales, 1996). Assim, são necessários estudos visando encontrar novas fontes de plantas inseticidas com o intuito de viabilizar o seu uso no campo com custo razoável e controle eficiente dessa praga.

O Departamento de Entomologia, Fitopatologia e Zoologia Agrícola da ESALQ/USP tem desenvolvido, nos últimos anos, diversas pesquisas visando avaliar a atividade de plantas da família Meliaceae em relação a pragas como Spodoptera frugiperda (J. E. Smith) e Tuta absoluta 
(Meyrick), tendo sido obtidos resultados promissores com algumas espécies dessa família, como Trichilia pallida Swartz e Melia azedarach L. (Rodríguez, 1995; Roel, 1998; Thomazini, 1999; Torrecillas, 1997 e Vendramim \& Scampini, 1997). Com essas espécies, foram obtidos, em relação a $S$. frugiperda, resultados semelhantes aos registrados com Azadirachta indica A. Juss (Rodríguez, 1995 e Torrecillas, 1997), meliácea considerada atualmente a mais eficiente planta inseticida (Koul et al., 1990; Mordue (Luntz) \& Blackwell, 1993; Rodríguez, 1995; Schmutterer, 1988 e Vendramim, 1997).

Assim, considerando a potencialidade dos derivados vegetais de meliáceas, objetivou-se, no presente trabalho, determinar o efeito de extratos aquosos de $T$. pallida e de $M$. azedarach, em comparação com o extrato aquoso de sementes de $A$. indica, sobre a mosca branca $B$. tabaci biótipo $B$. 


\section{REVISÃO DE LITERATURA}

\subsection{Considerações gerais sobre Bemisia spp.}

\subsubsection{Aspectos taxonômicos}

As moscas brancas pertencem à ordem Hemiptera, subordem Sternorrhyncha e família Aleyrodidae, a qual é subdividida em duas subfamílias: Aleyrodicinae e Aleyrodinae. Já foram descritas cerca de 1200 espécies de moscas brancas (mais de $90 \%$ na subfamilia Aleyrodinae); entretanto, acreditase que esse número seja muito maior. A distribuição das espécies no globo terrestre ocorre em função da latitude, concentrando-se a grande maioria (724 espécies) nos trópicos (Bink-Moenen \& Mound, 1990).

As similaridades entre os adultos de mosca branca de diferentes espécies têm levado os taxonomistas a basear sua classificação na estrutura do pupáriol (Martin, 1987). Isso tem causado confusão, uma vez que esse caráter é influenciado pela planta hospedeira da ninfa. Do ponto de vista taxonômico, esse caráter é vantajoso devido ao fato do inseto ficar aderido à folha nesse estágio, propiciando informações úteis sobre a planta hospedeira, porém tem a desvantagem da estrutura labial sofrer adaptações de acordo com a espessura da folha, dificultando a discriminação de espécies e principalmente de biótipos. Bemisia tabaci (Gennadius, 1889), por exemplo, apresenta variações morfológicas nessa estrutura quando se alimenta em hospedeiros glabros e pilosos, o que pode ocasionar erros na identificação. Como são esperadas variações contínuas na preferência pelo hospedeiro, ciclo de vida e 
capacidade de transmissão de doenças entre populações de diferentes habitats (Coudriet et al., 1985b), pode ser necessária a criação da população a ser identificada em diferentes hospedeiros procedendo-se o exame da variação dentro e entre as amostras de inúmeras localidades (Bedford et al., 1994), o que pode ser feito com o emprego de técnicas de eletroforese enzimática e análise de DNA (Brown et al., 1995).

Cohen et al. (1992) compararam diferentes linhagens de B. tabaci com respeito a características biológicas como capacidade de indução de dano, adequação hospedeira, razão de desenvolvimento e capacidade de transmissão de viroses. Foram verificadas muitas diferenças entre as linhagens, o que pode ser explicado pela adaptação da linhagem à planta hospedeira.

Mound (1983) enfatizou que uma lista completa de plantas hospedeiras não irá refletir a biologia típica em qualquer local. Além disso, destacou que quando uma espécie é introduzida numa área apenas parte de sua variabilidade genética é transferida, o que pode explicar o surgimento de biótipos.

Burban et al. (1992) coletaram várias populações de B. tabaci e distinguiram biótipos pela adequação hospedeira. A população coletada em mandioca só se desenvolveu bem em berinjela, porém a população coletada em berinjela se desenvolveu também em quiabo. Com base nos resultados, foram identificados dois biótipos, um que se desenvolve em berinjela e em mandioca e outro polífago, mas que não se desenvolve em mandioca.

Isto provavelmente explique o insucesso de Costa \& Russell (1975), ao tentarem, por diversas vezes, colonizar mandioca com B. tabaci, no Brasil. Por outro lado, a não ocorrência do biótipo adaptado à referida cultura, explicaria a não constatação do vírus do mosaico da mandioca no Brasil, o qual, segundo Fauquet \& Fargette (1990), é transmitido pela mosca branca.

De acordo com Brown et al. (1995), o surgimento de biótipos nessa espécie é esperado uma vez que sua gama de hospedeiros é bastante ampla (cerca de 500 espécies), tendendo à formação de populações 
monófagas em função da capacidade de adaptação na planta hospedeira.

No continente americano, o biótipo $B$ foi registrado na década de 80 , provavelmente introduzido através de plantas ornamentais importadas, sendo então disseminado para outras culturas de interesse econômico como feijão, mandioca, algodão, quiabo, melão, pimentão, abobrinha e fumo (Brown et al., 1995).

Em 1986, foram constatados danos severos causados pela mosca branca em bico-de-papagaio na Flórida (Perring et al., 1991), observando-se, a seguir, que esse inseto começou a demonstrar alta resistência aos inseticidas comumente utilizados o que despertou o interesse dos EUA em confirmar a presença de um novo biótipo de $B$. tabaci no seu território. Estes estudos permitiram caracterizar pelo menos dois biótipos: o biótipo $A$, que se desenvolve bem em algodoeiro, mas não em bico-de-papagaio, não induz o aparecimento do prateamento da folha em abobrinha e apresenta o padrão enzimático da esterase $A$, enquanto o biótipo $B$, que se desenvolve bem em bico-de-papagaio e brócolos, induz o prateamento da folha em abobrinha e apresenta o padrão enzimático da esterase B (Costa \& Brown, 1991; Cohen et al., 1992 e Perring et al., 1992). Ainda, Byrne \& Miller (1990) constataram que o biótipo B produziu maior quantidade de "honeydew" do que o biótipo A quando os insetos foram criados em bico-de-papagaio ou brócolos. Isso pode explicar a melhor adaptação do biótipo $\mathrm{B}$, que apresenta, por exemplo, maior número de hospedeiros e razão de oviposição duas vezes maior que a do biótipo $A$ (Betheke et al., 1991).

No Brasil, devido à ocorrência de surtos populacionais de mosca branca em hortaliças e ornamentais a partir do verão de 1990/91, Melo (1992) alertou para a possivel ocorrência de um novo biótipo no país. Lourenção e Nagai (1994), relatando surtos populacionais de $B$. tabaci em hortaliças e ornamentais no Estado de São Paulo, observaram 0 ataque do inseto associado ao prateamento das folhas com queda drástica de produção em aboboreira e amadurecimento irregular dos frutos em tomateiro (sintomas 
característicos do ataque do biótipo B, segundo Schuster et al., 1990 e Yokomi et al., 1990). Em função disso, também mencionaram a possibilidade de que um novo biótipo (ou uma nova espécie) teria sido introduzido no país, o que acabou sendo confirmado pela Dra. Judith Brown, da Universidade do Arizona (EUA), a partir de espécimes da mosca branca coletados em tomateiro no Distrito Federal (França et al., 1996).

Devido às diferenças anteriormente citadas entre os biótipos, além das diferenças morfológicas e genômicas e da incompatibilidade sexual entre os mesmos, Perring et al. (1993) admitiram a possibilidade de uma nova espécie de Bemisia. A caracterização do biótipo B como nova espécie (Bemisia argentifolii Bellows \& Perring) conforme consta em Bellows et al. (1994), com base nos danos característicos nas plantas hospedeiras, nas aberturas traqueais torácicas menores e no filamento de cera menor mais frágil no biótipo B e na ocorrência da seta submarginal ASMS4 somente nesse biótipo.

Após uma revisão do assunto, entretanto, Brown et al. (1995) sugeriram que $B$. tabaci é um complexo sofrendo mudanças evolucionárias. A maioria dos taxonomistas desse grupo de insetos, entretanto, tem considerado B. argentifolii como o biótipo B de B. tabaci (Vilarinho, informação pessoal), classificação adotada no presente trabalho.

\subsubsection{Distribuição geográfica e plantas hospedeiras}

Devido à interferência do homem na dispersão dos insetos, uma conclusão definitiva sobre o centro de origem de $B$. tabaci vai se tornando cada vez mais difícil (Brown, 1994 e Wool et al., 1994), porém acredita-se que essa espécie de mosca branca seja originária do subcontinente indiano, já que nessa região há abundância e diversidade de inimigos naturais (Brown et al., 1995). Segundo Brown et al. (1995), B. tabaci é um inseto multivoltino com 11 a 15 gerações por ano e tem como habitat regiões tropicais e subtropicais. É encontrada na África, América, Ásia e região do Mediterrâneo (Coudriet et al., 1985b, 1986; Murrant et al., 1988 e Vasquez et al., 1997). No Brasil, este inseto 
atualmente ocorre nos Estados de São Paulo, Minas Gerais, Goiás, Paraná, Distrito Federal, Bahia, Pernambuco (Submédio São Francisco), Ceará, Mato Grosso do Sul, Rio Grande do Norte, Tocantins e Rio de Janeiro (Villas Bôas et al., 1997).

Em algumas localidades dos Estados Unidos e Brasil, onde se encontrava apenas $B$. tabaci biótipo $A$, hoje tem-se constatado apenas o biótipo B (França et al., 1996 e Brown, 1994). Perring et al. (1994) explicaram esse deslocamento competitivo pelo comportamento de corte e cópula diferenciado entre os biótipos. $O$ biótipo $A$ realiza essa atividade em menos de um terço do tempo gasto pelo biótipo $B$. Os machos do biótipo $B$, embora demorem mais tempo no ritual de corte com fêmeas de $A$, não efetuam a cópula, mas ao mesmo tempo impedem que o macho de $A$ o faça. Por outro lado, a cópula entre indivíduos de $B$ não é afetada, uma vez que o tempo de corte entre macho de $A$ e fêmea de $B$ é curto.

Os hospedeiros preferenciais da mosca branca são: cucurbitáceas (abobrinha, melancia, melão e chuchu), solanáceas (tomate, berinjela, pimentão, fumo, pimenta e jiló), brássicas (brócolos e repolho), leguminosas (feijão, feijão-vagem), algodão, mandioca, alface e quiabo, além de plantas ornamentais, daninhas e silvestres (Caballero, 1994; Mello, 1992 e Villas Bôas et al., 1997). Brown et al. (1995) relataram que a gama de plantas hospedeiras de Bemisia spp. tem aumentado no decorrer do tempo, o que tem sido atribuído, entre outras razões, ao uso de práticas agrícolas de monocultivo irrigado. Com a recente discussão a respeito de uma nova espécie de Bemisia, foi constatado que $B$. tabaci biótipo $A$ tem pouco mais de 100 plantas hospedeiras, enquanto que o biótipo $B$ já tem sido encontrado em mais de 500 espécies vegetais (Blua et al., 1995; Brown et al., 1995; Burban et al., 1992 e De Barro, 1995). A existência de uma associação entre biótipo e planta hospedeira poderá resultar, no futuro, biótipos específicos para um número restrito de plantas, considerando-se que deve haver um custo adaptativo na manutenção de um largo espectro de hospedeiros. 


\subsubsection{Aspectos morfológicos e ecológicos}

Os ovos de B. tabaci são piriformes, com coloração amarela, e medem cerca de 0,2 a 0,3 mm (Byrne \& Bellows, 1991e Villas Bôas et al., 1997). São dispostos isoladamente ou em grupos irregulares, ou ainda, ocasionalmente, em semicírculos. São sustentados por um pedicelo inserido na folha durante a oviposição, fora da abertura dos estômatos (Eichelkraut \& Cardona, 1989; Paulson \& Beardsley, 1985).

As ninfas inicialmente são móveis, mas posteriormente se fixam num local adequado para a tomada de alimento, onde permanecem até o final do estágio. Ao final do quarto ínstar, há um período em que a ninfa não se alimenta, o qual muitas vezes é chamado de pupa; esse termo, entretanto, é inadequado, uma vez que o inseto não sofre qualquer tipo de metamorfose caracterizando a passagem para um novo estágio (Brown et al. 1995; Byrne \& Bellows, 1991; De Barro, 1995; Norman et al. s.d. e Villas Bôas et al., 1997). Em função dessa peculiaridade, o tipo de desenvolvimento das moscas brancas é denominado neometabolia (Zucchi et al., 1993) para diferenciar da paurometabolia em que não ocorre essa fase de interrupção da alimentação.

Os adultos de $B$. tabaci têm o dorso amarelo-pálido e as asas brancas, medindo de 1 a $2 \mathrm{~mm}$, sendo a fêmea maior que o macho. Quando em repouso, as asas são levemente separadas, com os lados paralelos, deixando o abdome visivel (Villas Bôas et al., 1997).

A reprodução é sexuada ou por partenogênese arrenótoca (Byrne \& Bellows, 1991 e Eichelkraut \& Cardona, 1989). Como na maioria das espécies de mosca branca, as fêmeas de $B$. tabaci podem regular o sexo de seus descendentes, desde que tenham espermatozóides armazenados para selecionar a fertilização (Horowitz \& Gerling, 1992).

A maioria dos adultos emerge pela manhã (Hoffman \& Byrne, 1986 e Powell \& Bellows, 1992), sendo que os machos emergem antes das fêmeas (Gerling et al., 1986). A emergência não ocorre em temperaturas abaixo de $17^{\circ} \mathrm{C}$, entretanto, não há correlação entre o início da 
emergência e o fotoperíodo sugerindo a existência de um ritmo circadiano (Hoffman \& Byrne, 1986).

A razão sexual varia no decorrer do período de maior incidência (De Barro, 1995). Examinando a proporção entre os sexos de B. tabaci em campo de algodão, Horowitz e Gerling (1992) constataram a predominância de fêmeas no início do verão ocorrendo o inverso, porém com menor diferença entre os sexos, ao final dessa estação. Os autores concluíram que a alta qualidade e quantidade de nutrientes do hospedeiro no início do verão facilita o rápido aumento da população. Enkegaard (1993) também constatou correlação positiva entre o número de fêmeas de $B$. tabaci e a temperatura, sendo que o número delas foi sempre proporcionalmente maior que o de machos, principalmente em temperaturas mais elevadas, o que é explicado pela maior mortalidade de machos nessas temperaturas.

O local de oviposição tem efeito sobre os descendentes, uma vez que esses insetos, geralmente, se alimentam e ovipositam na mesma folha. Em um ambiente variável, esses insetos encontram várias espécies de plantas que diferem substancialmente na adequação aos fitófagos. Também existem diferenças de adequação dentro da mesma planta hospedeira, pois elas preferem folhas mais jovens (van Lenteren \& Noldus, 1990).

A influência da qualidade nutricional e do estresse hídrico sobre a seleção hospedeira para oviposição, entretanto, ainda não está clara. Skinner (1996b) observou que o biótipo B prefere ovipositar em algodão com maior estresse hídrico e com maior qualidade nutricional, mas o tempo gasto para o início da oviposição é tão curto que é improvável que o inseto tenha alcançado o floema e avaliado a qualidade nutricional do mesmo. O inseto é capaz de ovipositar em folhas com temperaturas variando entre 16 e $43^{\circ} \mathrm{C}$, o que favorece seu desenvolvimento em diversos habitats (Skinner, 1996a)

A seleção da planta após o pouso é feita por picadas de prova. Pollard (1955), descrevendo o hábito alimentar de B. tabaci em algodoeiro, registrou, como efeitos macroscópicos desta alimentação, a deposição de 
"honeydew" na folha, ocorrência de clorose pela saliva da ninfa removendo clorofila e amido, desenvolvimento de antocianina, queda de folhas e redução na razão de crescimento. Os estiletes das ninfas alcançam o floema por penetração intercelular. A bainha estiletar ou salivar é rara e de constrição anular. Em $82 \%$ dos casos, o floema foi alcançado e o dano nos tecidos se restringiu à destruição de alguns cloroplastos adjacentes e plasmólise ocasional. O floema não foi bloqueado nem danificado.

Após o pouso, a discriminação da planta pelo inseto é feita com base em características físicas externas e químicas internas. Berlinger (1986) citou, como características físicas externas importantes para Bemisia spp., a pilosidade, os tricomas glandulares, o formato de folha e, provavelmente, o microclima, destacando o $\mathrm{pH}$ da folha como a principal característica química interna. Estudos de microscopia eletrônica do ápice do lábio de seis espécies de mosca branca, incluindo $B$. tabaci, revelaram que todas possuem sete pares de sensilos simetricamente posicionados sobre ou ao lado do encaixe labial, com função aparentemente quimio-sensorial (Walker \& Gordh, 1989).

As fêmeas de $B$. tabaci ovipositam preferencialmente na face abaxial das folhas jovens, com pilosidade moderada (Butler \& Wilson, 1984, Patel et al., 1992), o que se deve, segundo Butler et al. (1988), ao fato desse tipo de folha conferir proteção contra o vento e dessecação.

Segundo Costa et al. (1991), B. tabaci não discrimina entre plantas sadias e infectadas e/ou com diferentes niveis de aminoácidos nas folhas durante a oviposição em diferentes espécies de hospedeiros. As ninfas, no entanto, se desenvolvem melhor em plantas sadias.

Costa et al. (1993) observaram que a alimentação contínua de 20 adultos em abóbora não foi suficiente para induzir danos, o que ocorreu, no entanto, com apenas duas ninfas por planta durante 14 dias; a severidade dos danos foi crescente com o número de ninfas. Isso implica que baixos níveis populacionais de adultos não são capazes de induzir danos diretos e, dessa forma, repelentes de oviposição e seleção de cultivares desfavoráveis ao 
desenvolvimento ninfal são importantes no controle desse inseto.

\subsubsection{Aspectos biológicos de B. tabaci biótipo B}

A biologia desse inseto varia de acordo com a planta hospedeira e a temperatura.

A fase de ovo apresenta, à temperatura entre 25 e $27^{\circ} \mathrm{C}$, duração em torno de 5 a 8 dias, independentemente da planta hospedeira (Bethke et al., 1991; Tsai \& Wang, 1996; Wang \& Tsai, 1996 \& Yee \& Toscano, 1996). Excepcionalmente, Enkegaard (1993) observou em algodão uma duração dessa fase em torno de 14 dias a $25^{\circ} \mathrm{C}$. Wagner (1995) observou em algodão que o período de incubação variou de 5 a 9 dias nas temperaturas entre 21,77 e $34,66^{\circ} \mathrm{C}$; abaixo dessa temperatura, o alongamento da fase foi mais acentuado atingindo até 22,4 dias a $15,42^{\circ} \mathrm{C}$. Em berinjela, em temperaturas variando de 15 a $35^{\circ} \mathrm{C}$, Wang \& Tsai (1996) registraram valores de 4,2 a 25,8 dias, sendo que abaixo de 20 e acima de $30^{\circ} \mathrm{C}$, ocorreu alongamento da fase.

A viabilidade dos ovos é superior a $90 \%$ na faixa de temperatura entre 20 e $30^{\circ} \mathrm{C}$ (Enkegaard, 1993; Wagner, 1995; Tsai \& Wang, 1996 e Wang \& Tsai, 1996). Em temperaturas acima de $30^{\circ} \mathrm{C}$ ou abaixo de $20^{\circ} \mathrm{C}$, há uma tendência de diminuição da viabilidade (Enkegaard, 1993e Wang \& Tsai, 1996).

A fase ninfal apresenta, entre 25 e $27^{\circ} \mathrm{C}$, duração em torno de 12 a 16 dias (Bethke et al., 1991; Wagner, 1995; Tsai \& Wang, 1996; Wang \& Tsai, 1996 e Yee \& Toscano, 1996). Enkegaard (1993) observou, em bico-depapagaio, que essa fase foi prolongada em temperaturas abaixo de $20^{\circ} \mathrm{C}$. Em berinjela, Wang \& Tsai (1996) observaram que, a $30^{\circ} \mathrm{C}$, o período ninfal foi de apenas 9,4 dias, enquanto que abaixo de $25^{\circ} \mathrm{C}$ e acima de $30^{\circ} \mathrm{C}$, o referido período se alongou, atingindo 79,1 dias a $15^{\circ} \mathrm{C}$.

O efeito da planta hospedeira na duração da fase ninfal foi observado por Tsai \& Wang (1996), que trabalhando a $25^{\circ} \mathrm{C}$, em plantas de berinjela, tomate, batata-doce, pepino e feijão, encontraram 11,$35 ; 11,75 ; 12,00$; 12,97 e 14,95 dias, respectivamente. 
A viabilidade ninfal é variável para temperaturas entre 20 e $30^{\circ} \mathrm{C}$, de 39 a 95\% (Enkegaard, 1993; Wagner, 1995; Tsai \& Wang, 1996 e Wang \& Tsai, 1996). A $16^{\circ} \mathrm{C}$, Enkegaard (1993) registrou apenas $6,19 \%$ de viabilidade ninfal do biótipo B em bico-de-papagaio. Variando a planta hospedeira, Tsai \& Wang (1996) observaram, a $25^{\circ} \mathrm{C}$, viabilidades ninfais de 48,$8 ; 93,9,62,7 ; 71,3$ e $48,1 \%$, em plantas de pepino, berinjela, tomate, batata-doce e feijão, respectivamente. Avaliando o efeito de temperaturas entre 15 e $35^{\circ} \mathrm{C}$ sobre este parâmetro biológico, Wang \& Tsai (1996) observaram valores de 44,1 (a $15^{\circ} \mathrm{C}$ ) e $41,1 \%\left(a 35^{\circ} \mathrm{C}\right)$ até $93,9 \%\left(a 25^{\circ} \mathrm{C}\right)$ em berinjela.

O período do ovo a adulto pode demorar, em temperaturas entre 25 e $27^{\circ} \mathrm{C}$, de 16 a 25 dias, conforme a planta hospedeira (Tsai \& Wang, 1996; Wagner, 1995; Wang \& Tsai, 1996 e Yee \& Toscano, 1996), tendo sido registrado um valor de 17,96 dias em tomate, a $25^{\circ} \mathrm{C}$ (Tsai \& Wang, 1996). Enkegaard (1993) observou que, em bico-de-papagaio, em temperaturas inferiores a $20^{\circ} \mathrm{C}$, o inseto teve seu ciclo de vida prolongado. No intervalo de 17,63 a $34,75^{\circ} \mathrm{C}$, Wagner (1995) observou que o ciclo de vida do inseto tende a se prolongar abaixo de $17,2^{\circ} \mathrm{C}$ ou acima de $21,3^{\circ} \mathrm{C}$, mas as temperaturas extremas provocam um alongamento muito acentuado. Wang \& Tsai (1996), trabalhando em temperaturas variáveis entre 15 e $35^{\circ} \mathrm{C}$, observaram que a duração do período ovo-adulto, em berinjela, foi bastante afetada por esse fator, variando de 13,6 a 104,9 dias. A faixa de 25 a $30^{\circ} \mathrm{C}$ foi considerada ideal para o inseto, com alongamento do período de desenvolvimento fora dela.

A viabilidade do período de ovo a adulto, consequentemente, também é afetada pela planta hospedeira e temperatura, variando de 50 a $95 \%$, a $25^{\circ} \mathrm{C}$ (Enkegaard, 1993; Tsai \& Wang, 1996 e Wang \& Tsai, 1996). O efeito da planta hospedeira sobre esse parâmetro foi comprovada por Tsai \& Wang (1996) que encontraram, a $25^{\circ} \mathrm{C}$, valores de 88,$7 ; 60,2 ; 67,5 ; 46,4$ e $45,8 \%$, em berinjela, tomate, batata-doce, pepino e feijão, respectivamente.

O período de pré-oviposição pode levar de 2 a 4 dias, em função da temperatura (Enkegaard, 1993). 
A longevidade também apresenta bastante variação de acordo com a planta hospedeira e a temperatura; para fêmeas, esse período varia, em geral, de 10 a 20 dias em temperaturas entre 25 e $30^{\circ} \mathrm{C}$ (Bethke et al., 1991; Enkegaard, 1993; Tsai \& Wang, 1996 e Wang \& Tsai, 1996). Em berinjela, Wang \& Tsai (1996) observaram variação na longevidade de fêmeas de 10,43 a 44,36 dias, com redução desse período a $35^{\circ} \mathrm{C}$ e alongamento a $15^{\circ} \mathrm{C}$. A comprovação do efeito da planta hospedeira sobre a longevidade de fêmeas foi feita por Tsai \& Wang (1996), que observaram, a $25^{\circ} \mathrm{C}$, valores de 24,$03 ; 20,55$; 16,$56 ; 9,85$ e 13,38 dias em berinjela, tomate, batata-doce, pepino e feijão, respectivamente.

À semelhança do que foi constatado para os demais parâmetros biológicos, a fecundidade varia bastante em função da planta hospedeira e da temperatura, com valores entre 22 e 324 ovos/fêmea (Bethke et al., 1991; Enkegaard, 1993; Tsai \& Wang, 1996 e Wang \& Tsai, 1996). Tsai \& Wang (1996) obtiveram, a $25^{\circ} \mathrm{C}$, valores de fecundidade de 223,$67 ; 167,55 ; 77,50$; 65,96 e 83,50 ovos/fêmea, em berinjela, tomate, batata-doce pepino e feijão, respectivamente, enquanto Wang \& Tsai (1996) observaram que B. tabaci, mantida em berinjela, apresentou fecundidade variável entre 22 e 324 ovos/fêmea, em berinjela, na faixa de 15 a $35^{\circ} \mathrm{C}$, sendo que o menor valor foi registrado a $32^{\circ} \mathrm{C}$.

Betheke et al. (1991) observaram que o biótipo B é de duas a três vezes mais fecundo que o $A$ em algodão. Blua et al. (1995) observaram que os dois biótipos ovipositam em quantidade semelhante em pepino, mas em couve e beterraba, o biótipo $B$ oviposita mais que o $A$. Os autores rasparam levemente a superficie da folha de couve e constataram que os dois biótipos passaram a ovipositar semelhantemente, ficando clara a existência de algum mecanismo de seleção do inseto para oviposição conforme características físicas e/ou químicas da superfície foliar.

A razão sexual é sempre próxima de 0,70 , com predominância das fêmeas em relação aos machos (2 para 1 ) independentemente da temperatura 
(Enkegaard, 1993). Wagner (1995) avaliou a razão sexual do biótipo B em duas cultivares de algodão, em diferentes temperaturas, confirmando essa proporção entre os sexos. Sendo assim, o autor concluiu que esse parâmetro não é afetado pela planta hospedeira, temperatura ou época do ano.

\subsection{Extratos botânicos}

\subsubsection{Considerações gerais}

Antes mesmo do emprego dos inseticidas inorgânicos, já se utilizavam plantas com propriedades tóxicas, objetivando o controle de insetos pragas. A lista de plantas com atividade inseticida é bastante extensa e inclui grande número de familias botânicas (Arnasan et al., 1989; Grainge \& Ahmed, 1988; Lagunes et al., 1984 e Rodríguez \& Lagunes, 1990).

Dentre os primeiros fitoinseticidas utilizados, destacam-se a nicotina, extraída do fumo Nicotiana tabacum (Solanaceae), a rianodina extraída de Ryania speciosa (Flacuorticaceae), a sabadila oriunda de Schoenocalum officinale (Liliaceae), a piretrina, proveniente de Chrysantemum cinerariaefolioum (Asteraceae) e a rotenona extraída de Derris spp. e Lonchocarpus spp. (Fabaceae) (Lagunes \& Rodríguez, 1992). Estes produtos porém, praticamente deixaram de ser utilizados com o advento dos inseticidas organossintéticos, que se mostravam mais eficientes e baratos.

$\mathrm{O}$ ressurgimento dos estudos com plantas inseticidas deveu-se à necessidade de novos compostos para controle de pragas, sem os problemas de contaminação ambiental, resíduos nos alimentos, efeitos prejudiciais sobre os insetos benéficos e aparecimento de populações de insetos resistentes. Geralmente, os fitoinseticidas atendem esses requisitos, além de serem compatíveis com outros métodos de controle num sistema de manejo integrado de pragas e serem rapidamente biodegradados em comparação aos inseticidas sintéticos. Segundo McCloskey et al. (1993), inseticidas botânicos sintéticos 
análogos de bioquímicos naturais são mais aceitáveis no mercado do que os inseticidas convencionais por se considerar que estes são inócuos ao ambiente ou menos danosos ao homem e a outras espécies não alvo.

Segundo Vendramim (1997), as pesquisas com plantas inseticidas são feitas normalmente com dois objetivos: a descoberta de novas moléculas que permitam a obtenção de produtos sintéticos ou a obtenção de inseticidas botânicos naturais para uso direto no controle de pragas. Como exemplo de plantas inseticidas, no primeiro caso, o autor citou Physostigma venenosum (Fabaceae) cujos compostos secundários (especialmente a fisostigmina) foram tomados como modelo para a síntese de inseticidas carbamatos e $C$. cinerariaefolium, da qual se extraem as piretrinas, precursora dos piretróides. Em relação aos produtos botânicos naturais, foram mencionados os pós secos e os extratos aquosos que normalmente são utilizados logo após a obtenção e os produtos comerciais ou semi-comerciais, que, após a extração com solventes orgânicos, são misturados com substâncias inertes com a finalidade de facilitar a aplicação, evitar a rápida degradação ou aumentar a bioatividade.

$\mathrm{Na}$ década de 50, já eram conhecidas cerca de 2000 plantas com propriedade inseticida distribuídas em 170 famílias (Maranhão, 1954). Grainge \& Ahmed (1988) catalogaram 2.400 espécies de plantas com potencial para uso no controle de pragas, mencionando as características gerais da planta, ação sobre os insetos, além de uma listagem de 800 pragas controladas por essas plantas e ainda 100 plantas com substâncias químicas reportadas no controle de doenças e nematóides parasitas do homem e de animais.

Os principais efeitos causados pelos produtos vegetais com atividade inseticida sobre os insetos incluem repelência, inibição da oviposição, da alimentação e do crescimento, alterações do sistema hormonal, alterações morfogenéticas, alterações no comportamento sexual, esterilização dos adultos e mortalidade na fase imatura ou adulta (Koul et al., 1990; Mordue (Luntz) \& Blackwell, 1993; Rodríguez, 1995 e Schmutterer, 1988).

Em condições de laboratório ou casa de vegetação, estes efeitos 
podem ser determinados, mantendo-se os insetos em plantas tratadas (ou em folhas provenientes destas plantas) e avaliando-se a oviposição, consumo de alimento (em testes com e sem chance de escolha), duração do ciclo biológico, peso, tamanho, mortalidade das fases imaturas e da fase adulta, fecundidade, fertilidade e possíveis alterações morfogenéticas (Vendramim, 1997).

\subsubsection{Azadirachta indica A. Juss}

Esta planta, conhecida comumente como nim ou nime, é considerada a mais importante e promissora espécie vegetal com atividade inseticida (Hansen et al., 1993; Rodríguez, 1995; Schmutterer, 1990 e Vendramim, 1997).

A. indica apresenta os mais diferentes mecanismos de ação sobre os insetos incluindo inibição alimentar, redução de motilidade intestinal, interferência na sintese do ecdisônio, inibição da biossintese da quitina, deformações em pupas e adultos, redução na fecundidade e longevidade de adultos, alterações na atratividade dos feromônios, esterilização e inibição de oviposição e mortalidade (Koul et al., 1990; Mordue (Lutz) \& Blackwell, 1993 e Schmutterer, 1988).

De acordo com Balandrin et al. (1988), dos 25 componentes voláteis identificados a partir do nim, $75 \%$ destes estavam presentes nas sementes. A azadiractina, um dos principais componentes da semente de nim, tem importante ação sobre insetos de diversas ordens, como Orthoptera, Hemiptera, Coleoptera, Lepidoptera e Diptera (Schmutterer, 1988).

Com o objetivo de avaliar a bioatividade dos compostos inseticidas do nim em relação a Spodoptera littoralis (Boisduval), em função da polaridade do solvente extrator, Ascher et al. (1984) compararam a inibição do crescimento e fecundidade do inseto em substratos tratados com extratos aquosos e extratos obtidos com metanol, etanol, acetona, álcool isopropílico, n-butanol, clorofórmio, tetracloreto de carbono e n-pentano. Os extratos mais tóxicos 
foram aqueles obtidos com os solventes mais polares (constante dielétrica $>20$ ): água $(78,5)$, metanol $(32,6)$, etanol $(24,3)$ e acetona $(20,7)$.

Em relação à dose e aos efeitos ocasionados pela azadiractina nos insetos, Jacobson (1988) afirmou que a sua eficiência pode ser demonstrada na concentração de até $0,1 \mathrm{ppm}$, destacando que formulações obtidas de sementes têm sido utilizadas por agricultores de países desenvolvidos há vários anos. Govindachari (1992) e Rembold (1988) mencionaram que efeitos tóxicos mais acentuados são obtidos a partir de concentrações maiores que 100 ppm. Segundo Yoshida \& Toscano (1994), a azadiractina é mais tóxica que a rotenona, rianodina, sabadila e piretro.

Os extratos aquosos e etanólicos do nim têm ação sistêmica, sendo absorvidos pelas raízes e translocados pela planta, o que segundo Jacobson et al. (1978) e Munakata (1977), é uma característica importante no manejo de insetos sugadores como a mosca branca.

Segundo Isman et al. (1990) e Mordue (Luntz) \& Blackwell (1993), diversos isômeros da azadiractina já foram isolados (A a I); dentre esses, o isômero $A$ é o que ocorre em maior proporção (83\%), vindo a seguir o $B$, enquanto os demais isômeros ( $C$ a $I$ ) são encontrados em baixas concentrações. A molécula de azadiractina apresenta duas partes: a decalina e o grupo hidroxil furano, responsáveis pela inibição do crescimento e da alimentação, respectivamente (Aldhous, 1992).

Existem várias técnicas para se extrair e isolar a azadiractina. Entretanto, como isso é uma tarefa onerosa, esta substância tem sido usada através de produtos comerciais e semi-comerciais formulados a partir de extratos de nim (Koul, 1992; Mordue (Luntz) \& Blackwell (1993) e Soon \& Bottrell (1994). Jarvis et al. (1998) verificaram que a azadiractina é mais estável em soluções aquosas medianamente ácidas ( $\mathrm{pH}_{4}$ e 6) em temperatura ambiente e quando estocada em soluções orgânicas neutras pode permanecer estável por meses. Os resultados obtidos com extratos oriundos de nim têm sido altamente satisfatórios a ponto de incentivar a produção comercial de um 
grande número de formulações, que têm sido utilizadas para controle de diversas pragas (Aviles et al., 1995; Mordue (Lutz) \& Blackwell, 1993 e Soon \& Botrell, 1994).

Além do grande potencial inseticida, o nim possui outras características benéficas como a baixa toxicidade a mamíferos e a rápida degradação, com período de carência entre 4 e 10 dias, dependendo das condições ambientais e da planta tratada (Koul et al., 1990 e Schmutterer, 1988). Entretanto, a velocidade de degradação é diminuída quando se acrescenta um surfactante (Jarvis et al., 1998).

Por todas estas características, o nim tornou-se a planta inseticida mais estudada nos últimos 15 anos, sendo assunto de diversas revisões (Arnasan et al., 1989; Ascher, 1993; Centro Agronómico Tropical de Investigaciones y Enseñanza (CATIE), 1991; Govindachari, 1992; Jacobson, 1988; Jotwani \& Srivastava, 1981; Mordue (Luntz) \& Blackwell, 1993; Schmutterer, 1988, 1990; Subrahmanyam, 1990 e Warthen Jr., 1979, 1989). Já foram realizadas três conferências internacionais (International Neem Conference (INC 1, 1981; INC 2, 1984; INC 3, 1987) e dois eventos americanos (USDA Neem Workshop, 1990; Pacific Science Congress, 1993) que trataram exclusivamente de aspectos relacionados ao nim.

\subsubsection{Efeito de extratos botânicos sobre Bemisia spp.}

Muitos extratos de plantas já foram testados para controle de $B$. tabaci, tendo sido observados efeitos diversos sobre o inseto desde a inibição da oviposição e alimentação até a mortalidade nas diversas fases do ciclo biológico dessa praga. Dentre as plantas testadas, o nim tem se destacado como uma das mais eficazes.

Coudriet et al. (1985a), aplicando o extrato aquoso de nim a 0,2 e $2 \%$ sobre plantas de algodão, em condições de laboratório e casa de vegetação, observaram menor crescimento populacional de $B$. tabaci devido à redução na 
oviposição e na viabilidade dos ovos, alongamento do período ninfal e mortalidade de ninfas (principalmente no primeiro ínstar). Os efeitos sobre o desenvolvimento foram mais acentuados a $2 \%$. A redução da oviposição (resultante da repelência dos adultos) foi constatada mesmo aos 7 dias após a aplicação, em teste sem chance de escolha e aos 14 dias após, em teste com chance de escolha.

Prabhaker et al. (1989) testaram alguns inseticidas e o extrato de sementes de nim em laboratório contra duas linhagens de $B$. tabaci (uma suscetivel e outra resistente aos inseticidas convencionais). Os autores avaliaram a dose letal $\left(D_{50}\right)$ em cada fase do inseto e os niveis de resistência nas diferentes fases. $A D_{50}$ do extrato de nim foi maior do que os outros produtos, porém, os insetos apresentaram menores índices de resistência a esse extrato em todos os estágios. A linhagem resistente exigiu maior $\mathrm{DL}_{50}$ do que a suscetivel. Em todos os tratamentos, a fase mais difícil de ser controlada foi a de ovo, vindo a seguir a fase de "pupa", enquanto as ninfas de primeiro e segundo ínstares foram as mais sensiveis.

Natarajan \& Sundaramurthy (1990), testando o óleo de nim (0,5 e $1 \%)$ sobre ninfas de $B$. tabaci mantidas em folhas de algodão, em laboratório, constataram que apenas 14,3 e $13,0 \%$ das ninfas chegaram ao estágio adulto, dentre as quais 51,3 e $56,8 \%$, respectivamente, apresentaram anormalidades, enquanto nas testemunhas (monocotrofós a $0,08 \%$ e água), 84,3 e $94,0 \%$ das ninfas atingiram a fase adulta, com indices de anormalidade de 7,0 e 2,8\%, respectivamente. Dentre as anormalidades mais freqüentes, foram observadas a emergência incompleta dos adultos dos "pupários" e a má formação das asas.

Asiático \& Zoebisch (1992) compararam a eficiência de diversos produtos incluindo um extrato de sementes de nim (60 g/L água), o fungo entomopatogênico Verticillium lecanii ( $1 \mathrm{~g} / \mathrm{L}$ água), um detergente ( $2 \mathrm{~mL} / \mathrm{L}$ água) e o abamectin ( $60 \mathrm{~mL} / \mathrm{L}$ água) no controle da mosca branca $B$. tabaci em tomateiro. Foram feitas oito aplicações semanais. Embora todos os tratamentos tenham provocado a diminuição da população do inseto, houve transmissão de 
virose em $100 \%$ das plantas, demonstrando a necessidade de aumento na frequência das aplicações ou na dosagem.

Cubillo et al. (1994), avaliando a repelência provocada por três produtos à base de nim em dosagens variáveis entre 1 e $5 \mathrm{~mL} / \mathrm{L}$ sobre $B$. tabaci em plantas de soja em casa de vegetação, não constataram diferença no número de adultos nas plantas tratadas em relação à testemunha, embora a oviposição tenha sido bem menor nas plantas tratadas com duas das formulações, incluindo a utilizada na dosagem de $1 \mathrm{~mL} / \mathrm{L}$. Efeito semelhante foi encontrado com o emprego de extratos alcoólicos de uma mistura de pimenta e alho (1,2 e 4,4 g/L de água, respectivamente).

Puri et al. (1994), testando formulações à base de óleo de nim e de óleo de algodão, a 0,5 e 1\%, para controle de $B$. tabaci em algodoeiro, em condições de campo, constataram redução na população de ninfas e adultos em relação à testemunha, com eficiência similar à obtida com o inseticida fenpropatrin.

Em experimento semelhante, em tomateiro, Sabillón \& Bustamante (1995) utilizaram extratos aquosos de frutos verdes de Ricinus communis, de frutos maduros de $M$. azedarach e de sementes secas de nim (todos na concentração de $50 \mathrm{~g} / \mathrm{L}$ de água). Os autores consideraram que nenhum dos tratamentos exerceu um controle efetivo do inseto, embora tenham verificado que, em média, para 10 avaliações, os três tratamentos reduziram a população de mosca branca, além de permitir a maior produção de frutos sadios nas parcelas com nim e com $M$. azedarach.

Liu \& Stansly (1995b) obtiveram baixo nivel de controle de adultos de $B$. tabaci biótipo $B$, em plantas de tomate, em laboratório, usando um produto comercial à base da solanácea Nicotiana gossei (0,5, 1,0 e 2,0 g i.a./L). $O$ efeito sobre ninfas, entretanto, foi bastante acentuado, provocando mortalidades de $92,0 \%$ nos primeiros ínstares e de $88,7 \%$ em ninfas de maior idade (contra 3,0 e 6,4\%, respectivamente, nas plantas não tratadas). Acima de $0,2 \%$, no entanto, o extrato foi fitotóxico, produzindo, principalmente nas folhas 
jovens, cloroses irregulares e necroses nas margens ou em toda a folha.

Liu \& Stansly (1995a) testaram um produto comercial do nim em nove dosagens (variáveis entre 5 e $80 \mathrm{mg}$ de azadiractina/L água) sobre ninfas de $B$. tabaci biótipo $B$ em tomateiro sob condições de laboratório. Aplicações feitas sobre ninfas de primeiro ínstar provocaram mortalidade significativa em todos os tratamentos. No entanto, os autores consideraram que o controle só foi satisfatório a partir de $40 \mathrm{mg}$; com a aplicação da maior dosagem sobre ninfas de segundo e terceiro ínstares, o controle foi de cerca de $60 \%$.

Leskovar \& Boales (1996) testaram um produto comercial à base de azadiractina ( $3 \%$ de i.a.), para controle de $B$. tabaci biótipo $B$, em algodoeiro, em condições de campo. Mesmo empregando dosagem de $44 \mathrm{~g} / \mathrm{ha}$ (suficiente para um eficiente controle de lepidópteros), não foram obtidos resultados satisfatórios.

Nardo et al. (1997), avaliando o efeito do extrato aquoso obtido por infusão de partes iguais de folhas e frutos de $M$. azedarach, na concentração de 1:5 $(\mathrm{p} / \mathrm{v})$, sobre $B$. tabaci, em plantas de feijão, constataram mortalidade de adultos e menor oviposição (provavelmente devido ao efeito deterrente na alimentação). Nardo \& Costa (1990) já haviam observado que esse mesmo extrato reduziu em 45 a $60 \%$ a eficiência de transmissão de vírus do mosaico do feijoeiro por esse inseto.

Gómez et al. (1997a), avaliando diversas formulações comerciais de nim em relação à repelência, mortalidade dos adultos e oviposição de $B$. tabaci, em plantas de feijão, constataram que nenhuma delas foi letal ou repelente e apenas uma reduziu a oviposição. Em experimento semelhante, Gómez et al. (1997b) testaram 27 extratos de plantas não meliáceas, constatando que 20 deles foram repelentes, 17 reduziram a sobrevivência dos adultos e 17 diminuíram a oviposição dos insetos. Os extratos etanólicos ( $7 \mathrm{~g} / \mathrm{L}$ água) de Ruta graveolens, Cymbopogon citratus, Gliricidia sepium, Drymis granadensis, Chenopodium ambrosiodes e o azeite de Piper aduncum (1 mL/L água) se destacaram em relação ao efeito inseticida. Apesar desses resultados, 
os autores concluíram que a repelência não foi suficiente para suprimir os danos causados pelo inseto.

Cubillo et al. (1997) testaram os extratos aquoso e metanólico de Quassia amara em seis concentrações (variáveis entre 5 e $50 \%$ ) sobre $B$ : tabaci em plantas de feijão, em casa de vegetação, avaliando a repelência, mortalidade dos adultos e oviposição. Os dois tipos de extrato afetaram os três parâmetros, sendo que os extratos metanólicos apresentaram maior bioatividade que os aquosos, com uma relação direta entre o aumento da dosagem e a mortalidade, o que não ocorreu com o extrato aquoso.

Prabhaker et al. (1999) avaliaram o efeito do nim sobre $B$. tabaci biótipo B, em algodoeiro, comparando uma formulação comercial (3\%, a 30 e 60 ppm) e um extrato de sementes de nim (1\%) com e sem uréia, aplicando os produtos na semente e no solo. O extrato de sementes (sem uréia) foi ainda aplicado nas folhas. Nenhum dos tratamentos provocou um atraso no desenvolvimento da fase imatura. Todos os tratamentos reduziram a oviposição (com exceção do nim a 1\% sem uréia) e reduziram a viabilidade dos ovos (com exceção da formulação a $30 \mathrm{ppm}$ na semente). A formulação a 30 ppm e o extrato sem uréia na semente; a formulação a 60 ppm e o extrato com e sem uréia no solo e a aplicação foliar do extrato propiciaram aumento no número de ninfas mortas, sendo as de primeiro ínstar as mais sensíveis. Em todos os tratamentos, houve redução no número de adultos emergidos. O efeito mais drástico sobre a oviposição ocorreu na aplicação foliar, seguindo-se o tratamento de solo e o tratamento de sementes. Considerando-se que tanto no tratamento de sementes como de solo, houve efeito sobre as formas imaturas, fica evidenciada a capacidade do nim se translocar na planta da região radicular até as folhas. Os autores ainda consideraram que a maior mortalidade em ninfas de primeiro ínstar pode ser tanto pela toxicidade dos extratos, como pela sua repelência fazendo com que o inseto se locomova mais pela folha, se expondo ao ambiente.

A compatibilidade de inseticidas botânicos com inimigos naturais 
de Bemisia spp. tem sido testada, demonstrando que a avaliação do impacto desses extratos sobre a fauna benéfica deve ser considerada caso a caso.

Assim, Feldhedge \& Schmutterer (1993), avaliando o efeito de um produto comercial do nim nas concentrações de 10 e 20 ppm sobre o microhimenóptero Encarsia formosa Gahan, constataram efeito sobre a emergência de adultos, longevidade e capacidade de parasitismo, somente a $20 \mathrm{ppm}$.

Bentz \& Neal Jr. (1995), por outro lado, avaliando o efeito de extrato de $N$. gossei $(0,1 \%)$ e um produto comercial do nim $(0,624 \%)$ constataram que ambos causaram mortalidade pupal em $E$. formosa. O nim, aplicado sobre ninfas, não provocou efeito residual sobre os parasitóides quando estes foram liberados, após 1; 1,5 e 3 horas, observando-se que a distribuição foi semelhante nas plantas tratadas e não tratadas. Apesar de $N$. gossei apresentar certa toxicidade ao parasitóide, os autores, comparando com os efeitos provocados por outros inseticidas comuns, ponderaram que o referido extrato foi compativel com o parasitóide, principalmente em áreas em que é necessário um controle imediato, podendo se aplicar o extrato na área para se diminuir a população da praga e liberar o parasitóide em seguida. Liu \& Stansly (1996) comprovaram a compatibilidade desse extrato $(0,2 \mathrm{~g}$ i.a./ $\mathrm{L}$ água) e do óleo mineral $(0,2 \%$, v:v) sobre o predador Nephaspis oculatus (Blatchley) em todos as suas fases de desenvolvimento.

Stansly \& Liu (1997), avaliando o efeito de dois produtos comerciais derivados de plantas (nim a $0,06 \mathrm{~g}$ i.a./L e $\mathrm{N}$. gossei a 0,1, 0,2 e 0,4 g i.a./L) sobre Encarsia pergandiella Howard, verificaram que os extratos afetaram o inseto em todas as fases imaturas, exceto as pupas e larvas com sete dias. $O$ efeito residual sobre os adultos foi insignificante.

\subsubsection{Efeito de extratos de meliáceas sobre outros insetos sugadores}




\section{fitófagos}

Os extratos de meliáceas causam vários efeitos nos insetos, atuando como deterrentes, reguladores de crescimento e esterilizantes. $O$ efeito residual depende das condições ambientais, podendo persistir por 4 a 8 dias. $\mathrm{Na}$ forma sistêmica, o efeito geralmente é mais prolongado. Diante disso, em condições de campo, são exigidas quantidades maiores para se alcançar resultados semelhantes aos obtidos em laboratório. Devido à ação lenta do nim, este é inadequado quando a planta não suporta mais danos ou quando seu efeito máximo no inseto se dá após o pico populacional da praga (Schumutterer, 1988).

Abraham \& Ambika (1979) observaram que os extratos acetônicos de folhas e sementes de nim interferem na ecdise do percevejo Dysdercus cingulatus Fabr. Os extratos, aplicados topicamente, provocaram aumento de um ínstar em relação aos insetos criados na testemunha. Os indivíduos que chegaram ao estágio adulto apresentaram os ovaríolos degenerados quando tratados com qualquer um dos extratos de nim.

Pandey et al. (1981) testaram o extrato obtido com éter de petróleo de frutos maduros de $M$. azedarach, nas concentrações de $0,5,1$ e $2 \%$, sobre o percevejo Bagrada cruciferarum Kirk., constatando efeito tanto em laboratório como no campo. A $2 \%$, a mortalidade foi de $93,3 \%$ no laboratório e de $100 \%$ no campo, $24 \mathrm{~h}$ após a aplicação do produto.

Mariappan \& Saxena (1983b) testaram extratos metanólicos de sementes de nim e de Annona squamosa L. sobre a cigarrinha Nephotettix virescens (Distant). Nas concentrações de 5, 10, 20, 30 e 50\%, houve alta mortalidade de adultos e redução na eficiência de transmissão de virose no arroz em relação à testemunha. Usando os mesmos extratos, a 5, 10 e 20\%, e misturando os dois extratos em todas as combinações pares possíveis, os autores constataram que em mistura os extratos foram mais efetivos do que isoladamente (Mariappan \& Saxena, 1983a).

Saxena \& Khan (1985b) constataram efeito deletério de nim sobre 
a cigarrinha Nilaparvata lugens (Stal), além de diminuir sua eficiência na transmissão de viroses; entretanto, a concentração exigida foi de $6 \%$. Segundo Saxena et al. (1993), o óleo de nim também interfere na emissão de sinais de corte e cópula em fêmeas de $N$. lugens, impedindo o encontro de machos e fêmeas.

Saxena \& Khan (1985a) avaliaram o efeito de nim nas concentrações de 1,$25 ; 2,5 ; 5$ e $10 \%$ sobre o comportamento alimentar de $N$. virescens em arroz. Foram feitas aplicações foliares, avaliando-se o número de picadas de prova e os tempos de salivação, ingestão de floema, ingestão de xilema e ingestão total. Houve maior número de picadas de prova, menor tempo de ingestão de floema (a 5 e 10\%, nem houve alimentação nesse local), maior tempo de ingestão no xilema e menor tempo total nas plantas tratadas em relação à testemunha. Saxena \& Boncodin (1988a) fizeram um trabalho semelhante com essa mesma espécie de inseto em arroz, utilizando, contudo, aplicações foliares e sistêmicas. Nas duas aplicações, houve maior número de picadas de prova, menor tempo de ingestão no floema, maior tempo de ingestão no xilema e menor tempo total em relação à testemunha. $\mathrm{Na}$ aplicação sistêmica, os efeitos foram mais acentuados e o tempo de salivação também foi maior do que na testemunha e na aplicação foliar. O menor tempo de alimentação no floema é importante porque o inseto tem menor chance de adquirir e transmitir viroses.

Saxena \& Boncodin (1988b) avaliaram o efeito do extrato de sementes de nim na sobrevivência de $N$. virescens e na sua capacidade de transmitir viroses em arroz. O extrato $(2500 \mathrm{ppm})$ foi aplicado na folha e sistemicamente através da imersão da raiz em solução com extrato por $24 \mathrm{~h}$. $\mathrm{Na}$ aplicação sistêmica, a sobrevivência caiu progressivamente do $2^{\circ}$ ao $5^{\circ}$ dia após a aplicação e na aplicação foliar não houve efeito na sobrevivência. A capacidade de transmissão de vírus também foi bastante diminuída na aplicação sistêmica em relação à testemunha, embora na aplicação foliar também tenha ocorrido diferença na capacidade de transmissão em relação à 
testemunha.

Isman et al. (1990) extraíram o óleo de sementes de nim oriundo de diferentes locais, encontrando diferença significativa nas concentrações de azadiractina entre as amostras. De modo geral, o óleo de sementes de nim afetou o crescimento e foi repelente à cigarrinha Oncopeltus fasciatus Dallas, sendo este efeito mais acentuado com maiores concentrações de azadiractina, o que indica que a concentração dessa substância serve como um parâmetro para determinar a qualidade do extrato de nim.

Em geral, o extrato de nim é um ótimo aficida em condições de campo e laboratório; entretanto, essa eficiência é bastante influenciada pela planta hospedeira, espécie de afídeo e condições ambientais (Lowery et al., 1993).

Trabalhando com o pulgão Lipaphis rysimi Kalt., Singh et al. (1988) avaliaram os extratos aquoso, etanólico e hexânico de sementes de nim, constatando que este último foi mais eficiente.

West \& Mordue (1992) observaram que os pulgões Sitobium avenae e Rhopalosiphum padi reduzem o número de picadas de prova como mecanismo de escape de plantas de cevada tratadas com nim. Nesse trabalho, os autores obtiveram resultados semelhantes tanto em aplicação foliar como no solo (para atuação sistêmica). Outros autores já haviam testado o extrato de nim via sistêmica no controle de outros insetos com excelentes resultados (Gill \& Lewis, 1971). Segundo Osman \& Port (1990), a liberação gradual do composto de nim incorporado no solo e sua gradual absorção e translocação pela planta dá uma considerável persistência como agente de controle, já que, no solo, o composto fica protegido da luz solar, que degrada o produto.

Nisbet et al. (1993), avaliando o extrato de nim contra Myzus persicae (Sulzer) em fumo, verificaram que os pulgões fizeram mais picadas de prova, gastaram mais tempo entre as picadas de prova, ocorrendo aumento no número de perfurações sem alcançar os vasos liberianos, proporcionalmente à concentração do extrato. Em teste de livre escolha, as plantas com extrato 
foram menos preferidas. $\mathrm{O}$ extrato mostrou-se eficiente após pelo menos uma semana de aplicação, apresentando, no entanto, efeito deletério também sobre inimigos naturais. Schoonhoven \& Derksen-Koppers (1976) e Lowery \& Isman (1995) também constataram o efeito deletério de nim sobre $M$. persicae em concentrações acima de $1 \%$.

Dimetry \& El-Hawary (1995) constataram a eficiência do nim (0,5\%) já no primeiro ínstar do pulgão Aphis craccivora Koch onde ocorreu $75 \%$ de mortalidade. O período ninfal também foi alongado e aumentada a proporção de formas aladas.

Lowery e Isman (1995) constataram o efeito do nim sobre os inimigos naturais no campo, monitorando a população de afídeos, seus predadores e parasitóides, mas a proporção entre praga e inimigos naturais permaneceu semelhante evidenciando a compatibilidade do nim com os inimigos naturais. 


\section{MATERIAL E MÉTODOS}

Os experimentos foram desenvolvidos em condições de casa de vegetação e laboratório no Departamento de Entomologia, Fitopatologia de Zoologia Agrícola da ESALQ/USP, em Piracicaba, SP, com a mosca branca Bemisia tabaci (Gennadius, 1889) biótipo B e extratos aquosos de Melia azedarach L., Trichilia pallida Swartz e Azadirachta indica A. Juss (Meliaceae).

\subsection{Manutenção da criação estoque de $B$. tabaci}

A colônia, obtida a partir de uma criação do Setor de Entomologia do Centro de Fitossanidade do Instituto Agronômico de Campinas (IAC), foi mantida em uma casa de vegetação (com aproximadamente $2,5 \mathrm{~m}^{2}$ ), fechada lateralmente com tela de malha fina (impedindo a entrada elou saída de insetos) e com cobertura de vidro. Como hospedeiro para criação, foram utilizadas plantas de soja, com idade entre 15 e 30 dias, cultivadas em vasos de alumínio. A cada 15 dias, novas plantas de soja eram introduzidas em substituição àquelas em que já estava ocorrendo emergência dos adultos, as quais eram descartadas quando essa emergência se completava.

\subsection{Obtenção e manutenção das plantas de tomateiro}

A cultivar Santa Clara de tomate (Lycopersicon esculetum Mill.) foi mantida em cultivo em sacos plásticos (com capacidade para 10 litros) contendo solo esterilizado, irrigado e adubado regularmente. 


\subsection{Coleta e preparo dos extratos vegetais}

As folhas, ramos, frutos verdes e frutos maduros de $M$. azedarach e as folhas, ramos e córtex de $T$. pallida foram coletados em área de mata da ESALQ/USP, Piracicaba, SP. As sementes de de A. indica (nim), utilizadas como padrão de atividade inseticida nos dois últimos experimentos, foram provenientes de estoque existente no laboratório do Setor de Entomologia da ESALQ/USP. O material vegetal foi seco em estufa (a $40^{\circ} \mathrm{C}, 48 \mathrm{~h}$ ) (separadamente por estrutura vegetal) e posteriormente triturado até a obtenção de pó através de um moinho de faca. Estes materiais foram armazenados em recipientes hermeticamente fechados até o preparo dos extratos. Estes foram preparados misturando-se o pó de cada material (1,2 ou $3 \mathrm{~g}$ ) à água destilada $(100 \mathrm{ml})$. As suspensões resultantes foram mantidas em frascos por $24 \mathrm{~h}$ para permitir melhor extração dos compostos hidrossolúveis. Após esse período, as misturas foram filtradas com auxilio de um tecido fino, obtendo-se, então, os extratos aquosos a 1, 2 e $3 \%$ (peso/volume), respectivamente.

\subsection{Determinação da concentração adequada de extratos aquosos de $\boldsymbol{M}$. azedarach e de $T$. pallida para estudos de bioatividade em relação a $B$. tabaci biótipo B}

Foram avaliadas diferentes concentrações dos extratos aquosos de folhas de $M$. azedarach e de ramos de $T$. pallida, estruturas vegetais com atividade inseticida comprovada em relação a outras pragas (Rodríguez \& Vendramim, 1997, 1998; Roel, 1998; Thomazini, 1999; Torrecillas, 1997), visando selecionar a uma concentração adequada para ser utilizada no presente trabalho. Foram realizados dois experimentos: no primeiro, foram testadas as concentrações de 1 e $2 \%$ e no segundo, 1,2 e $3 \%$.

Nesses experimentos, foi utilizada uma pequena gaiola (confeccionada com tecido de "voil") que podia ser aberta e fechada por uma tira de Velcro ${ }^{\circledR}$ e que envolvia uma folha de cada planta de tomateiro (com 30 dias 
de idade) (Figura 1). Em cada gaiola, foram mantidos adultos (cerca de 30 indivíduos não sexados) de mosca branca durante $24 \mathrm{~h}$ para a oviposição. Após esse período, as gaiolas eram retiradas $e$ as folhas examinadas cuidadosamente, sendo selecionado um folíolo de cada planta contendo, no mínimo, 50 ovos. Então, os folíolos contendo os ovos eram pulverizados com os extratos, de modo a obter uma cobertura completa dos mesmos. Como testemunha, foram utilizados folíolos (também com, no mínimo, 50 ovos) pulverizados com água destilada. Os folíolos contendo os insetos em desenvolvimento foram mantidos sem as gaiolas até próximo do final da fase imatura (o que foi caracterizado pelo tamanho das ninfas), quando, então, foram novamente envolvidos pelas gaiolas para evitar a fuga dos adultos. Para cada tratamento, foram utilizados 4 folíolos (um por planta), em delineamento experimental inteiramente casualizado As variáveis avaliadas foram a mortalidade e a duração das fases de ovo e ninfa.

No primeiro experimento, foram testadas as concentrações de $1 \mathrm{e}$ $2 \%$, utilizando-se, em média, $61,53,61,71$ e 61 ovos por folíolo, nos tratamentos com M. azedarach, T. pallida, e testemunha, respectivamente. No segundo, além dessas, foi incluída a concentração de $3 \%$, utilizando-se, em média, $84,76,70,80,62,62$ e 70 ovos por folíolo nos tratamentos com $M$. azedarach a 1, 2 e 3\%, T. pallida a 1, 2 e 3\%, e testemunha, respectivamente.

Os resultados foram analisados pelo teste $F$, sendo as comparações entre as médias feitas através do teste de Tukey $(P \leq 0,05)$.

\subsection{Seleção das estruturas vegetais de $M$. azedarach e de $T$. pallida mais efetivas, na forma de extrato aquoso, em relação a $B$. tabaci biótipo $B$}

Foram avaliados os extratos, na concentração de $3 \%$, de folhas, ramos, frutos verdes e frutos maduros de $M$. azedarach e de folhas, ramos e córtex de $T$. pallida, com o objetivo de determinar a estrutura mais efetiva de cada planta sobre $o$ inseto. Estes experimentos foram realizados de forma 
independente para cada espécie vegetal, sendo que a obtenção dos ovos e a pulverização das plantas foram realizadas de acordo com o descrito no item 3.4, utilizando-se igualmente 4 folíolos (um por planta) por tratamento, em delineamento experimental inteiramente casualizado.

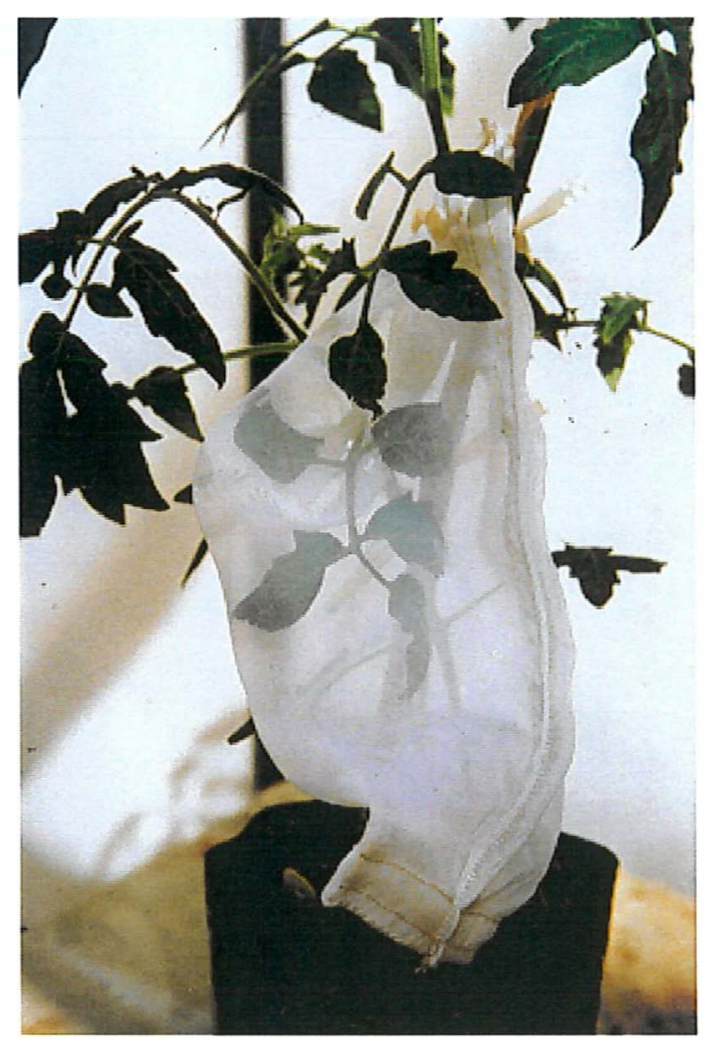

Figura 1. Gaiola utilizada nos experimentos com Bemisia tabaci biótipo B. 
P.ara cada espécie vegetal, foram realizados dois experimentos. No primeiro, foi feita apenas uma pulverização sobre os folíolos contendo ovos, avaliando-se a duração e mortalidade dessa fase. No segundo experimento, além da pulverização dos ovos, foi feita uma segunda aplicação sobre os folíolos quando as ninfas estavam com três dias de idade a partir da eclosão. Nesse experimento, o desenvolvimento do inseto foi acompanhando até a emergência dos adultos, avaliando-se a mortalidade e duração das fases de ovo e ninfa.

Para $M$. azedarach, no primeiro experimento, o número médio de ovos por folíolo foi $69,64,69,68$ e 62 nos tratamentos com ramos, folhas, fruto verde, fruto maduro e testemunha, respectivamente, enquanto no segundo, esse número foi $69,69,65,66$ e 57 , nos respectivos tratamentos.

Com relação a $T$. pallida, no primeiro experimento, o número médio de ovos por folíolo foi 57, 58, 52 e 66 nos tratamentos com ramos, folha, córtex e testemunha, respectivamente, enquanto no segundo, esse número foi $63,67,63$ e 52, nos respectivos tratamentos.

Os resultados foram analisados pelo teste $F$, sendo as comparações entre as médias feitas através do teste de Tukey $(P \leq 0,05)$.

\subsection{Efeito de extratos aquosos de três meliáceas sobre a biologia de $B$. tabaci biótipo B}

Nessa etapa, foram testados os extratos de ramos de $T$. pallida, de frutos verdes de $M$. azedarach em comparação com o extrato de sementes de $A$. indica (nim) na concentração de $3 \%$. Foram realizados dois experimentos, sendo a obtenção dos ovos e a pulverização das plantas com os extratos feitas conforme descrito no item 3.4.

No primeiro experimento, os extratos foram aplicados sobre os ovos e sobre as ninfas com três dias de idade e no segundo apenas sobre as ninfas com três dias. $O$ delineamento experimental, em ambos, foi o inteiramente casualizado, com 4 tratamentos (extrato de cada uma das meliáceas e com água 
destilada) e 5 repetições.

No primeiro experimento, foram utilizados folíolos contendo 103 , 147, 98 e 65 ovos nos tratamentos com M. azedarach, T. pallida, A. indica e testemunha, respectivamente, avaliando-se os mesmos parâmetros biológicos descritos no item 3.4 .

No segundo experimento, o número de ovos utilizados por folíolo foi, em média, 104, 145, 234 e 65 ovos, nos tratamentos com M. azedarach, $T$. pallida, $A$. indica e testemunha, respectivamente. Nesse experimento, foi utilizado um número maior de ovos visando garantir uma quantidade suficiente de insetos para avaliação da fase adulta. O número de adultos emergidos era anotado diariamente para avaliação da duração e viabilidade da fase ninfal, sendo então descartados. No dia em que ocorreu a emergência de, no mínimo, 75 adultos por tratamento ( 5 foliolos), os mesmos foram levados ao "freezer" por três minutos para que a redução da sua atividade permitisse a manipulação. Os adultos foram então reunidos em 5 grupos (repetições) de cerca de 15 indivíduos cada e transferidos para outros folíolos, mantidos em laboratório, à temperatura de $25,0 \pm 2,0^{\circ} \mathrm{C} ; 70,0 \pm 10,0 \%$ de UR e fotofase de $12 \mathrm{~h}$. Cada grupo foi isolado em uma pequena gaiola de acrílico, com a parte superior tampada com "voil" para permitir a aeração. Diariamente, era anotada a morte dos adultos, ocasião em que os mesmos eram retirados e sexados. Após a morte de todos os adultos numa gaiola, foi feita a contagem do número de ovos e ninfas em cada folíolo. Os parâmetros avaliados nesse segundo experimento foram: mortalidade ninfal, longevidade dos adultos (machos e fêmeas) e fecundidade (número de ovos/fêmea). Os resultados foram analisados pelo teste $F$, sendo as comparações entre as médias feitas através do teste de Tukey ( $P \leq$ $0,05)$. 


\section{RESULTADOS E DISCUSSÃO}

\subsection{Determinação da concentração adequada de extratos aquosos de Melia azedarach e de Trichilia pallida para estudos de bioatividade em relação a Bemisia tabaci biótipo B}

\subsubsection{Primeiro experimento}

Embora todos os tratamentos com extrato tenham provocado um aparente aumento na mortalidade de $B$. tabaci biótipo $B$, durante a fase de ovo, com valores variáveis entre 21,76 e $36,00 \%$, a diferença estatística em relação à testemunha (onde a mortalidade foi de $3,02 \%$ ) foi registrada apenas para o maior valor, obtido com folhas de $M$. azedarach a $2 \%$. A mortalidade ninfal não foi alterada pela aplicação dos extratos sobre os ovos, ainda que com T. pallida a $2 \%$ a mesma tenha atingido $33,98 \%$ contra $12,65 \%$ na testemunha. Nos demais tratamentos, os valores apresentaram pequena variação (11,66 a $14,04 \%)$. Considerando-se as mortalidades acumuladas nas fases de ovo e ninfa, constatou-se efeito apenas do extrato de ramos de $T$. pallida a $2 \%$, tratamento em que a mortalidade, ao final da fase imatura, atingiu $50,82 \%$, valor significativamente superior ao encontrado na testemunha $(15,29 \%)$, ocorrendo nos demais tratamentos valores intermediários (Tabela 1 e Figura 2).

A duração das fases de ovo (período de incubação) de ninfa e, consequentemente, da fase de ovo à emergência do adulto (ovo-adulto) não foi afetada pelos tratamentos, tendo sido registrados valores variáveis de 7,43 a 
7,94; 20,97 a 21,24 e 28,40 a 29,13 dias, respectivamente (Tabela 2).

\subsubsection{Segundo experimento}

Nesse experimento em que também foi incluída a concentração $3 \%$ das duas meliáceas, a mortalidade da mosca branca, durante a fase de ovo nos tratamentos com extrato de ramos de $T$. pallida a $3 \%(52,82 \%)$ e a $2 \%(37,33 \%)$ e com extrato de folhas de $M$. azedarach a $3 \%(32,61 \%)$ foi superior em relação à constatada na testemunha $(1,04 \%)$. Nos tratamentos com $M$. azedarach a $1 \mathrm{e}$ $2 \%$ e com $T$. pallida a $1 \%$, não houve efeito sobre a viabilidade dos ovos do inseto. Analogamente ao que foi observado no experimento anterior, também nesse, não foi registrada diferença estatística entre os valores de mortalidade ninfal, embora os mesmos tenham variado entre 9,40 e $30,66 \%$. O efeito na sobrevivência da fase ovo-adulto foi registrado nos tratamentos com $T$. pallida a 3 e $2 \%$ e com $M$. azedarach a $3 \%$, nos quais os valores médios $(61,11 ; 56,54$ e $52,80 \%$, respectivamente), diferiram significativamente do registrado na testemunha $(18,88 \%)$. Nos demais tratamentos, os valores de mortalidade foram intermediários (Tabela 3 e Figura 3).

Em relação à duração da fase imatura, apenas o período ninfal foi afetado (Tabela 4), constatando-se para os ovos tratados com extrato de $M$. azedarach a $1 \%$ um valor menor (24,69 dias) que o registrado na testemunha (25,53 dias), observando-se nos demais tratamentos valores intermediários. A duração das fases de ovo e ovo-adulto não foi afetada pelos tratamentos com médias variando de 12,51 a 13,02 e 37,30 a 38,33 dias, respectivamente (Tabela 4).

O alongamento do período de incubação e da fase ninfal no segundo experimento (Tabela 4) em relação ao primeiro (Tabela 2) 
provavelmente tenha sido devido à redução da temperatura na casa de vegetação, que oscilou, em média, de $18,4^{\circ} \mathrm{C}$ para $16,6^{\circ} \mathrm{C}$, do primeiro para o segundo experimento, considerando-se que, à semelhança do que ocorre com os insetos de modo geral, a velocidade de desenvolvimento de $B$. tabaci biótipo B aumenta com o aumento de temperatura na faixa de 15 a $30^{\circ} \mathrm{C}$ (Enkegaard, 1993; Wagner, 1995 e Wang e Tsai, 1996).

Comparando-se os dados dos dois experimentos, verifica-se que, tanto o extrato de ramos de $T$. pallida como o extrato de folhas de $M$. azedarach apresentaram efeito ovicida significativo apenas a $3 \%$. A $2 \%$, os resultados não foram concordantes estatisticamente nos dois experimentos embora, em ambos, a mortalidade causada pelos extratos, durante a fase de ovo, tenha sido aparentemente maior que na testemunha. Entretanto, considerando-se o nivel de probabilidade $(5 \%)$ previamente estabelecido, verificou-se que o extrato de $M$. azedarach eficiente no primeiro experimento não comprovou a sua eficiência no segundo experimento, ocorrendo o inverso com $T$. pallida que afetou significativamente a viabilidade dos ovos apenas no segundo experimento.

Analisando-se a mortalidade ninfal, verifica-se que nos dois experimentos, os extratos aplicados sobre os ovos não afetaram significativamente a sobrevivência das ninfas.

No que se refere à duração das fases imaturas, só foi verificado efeito com extrato de $M$. azedarach a $1 \%$ no segundo experimento, no qual o desenvolvimento da fase ninfal foi mais rápido com aplicação do extrato que na testemunha. Esse resultado foi inesperado, porque acreditava-se que, se houvesse algum efeito dos extratos, esse seria no sentido de retardar o desenvolvimento.

Levando-se em conta os resultados desses dois experimentos e considerando-se que as demais estruturas vegetais de $T$. pallida e $M$. azedarach podem apresentar menor bioatividade em relação à mosca branca, selecionouse a concentração de $3 \%$ como a mais adequada para uso nos experimentos visando à avaliação do efeito dos extratos de diferentes estruturas vegetais 
dessas meliáceas sobre a referida praga.

Tabela 1. Médias ( \pm EP) de mortalidade das fases de ovo, ninfa e ovo-adulto de Bemisia tabaci biótipo $\mathrm{B}$, em tomateiro, após aplicação de extratos aquosos de Trichilia pallida e Melia azedarach sobre os ovos. Temp.: $18,4 \pm 6,7^{\circ} \mathrm{C}$; UR: $72,4 \pm 21,9 \%$; fotoperiodo natural.

\begin{tabular}{lccc}
\hline \multirow{2}{*}{ Extratos } & \multicolumn{3}{c}{ Mortalidade (\%) } \\
\cline { 2 - 4 } & Ovo & Ninfa & Ovo-adulto \\
\hline M. azedarach 2\% & $36,00 \pm 2,57$ a & $11,66 \pm 7,75$ a & $44,46 \pm 6,73 \mathrm{ab}$ \\
M. azedarach 1\% & $27,92 \pm 23,43 \mathrm{ab}$ & $13,37 \pm 3,63$ a & $37,55 \pm 22,02 \mathrm{ab}$ \\
T. pallida 2\% & $25,51 \pm 4,87 \mathrm{ab}$ & $33,98 \pm 20,80$ a & $50,82 \pm 13,20 \mathrm{a}$ \\
T. pallida 1\% & $21,76 \pm 15,32 \mathrm{ab}$ & $14,04 \pm 16,99$ a & $32,75 \pm 22,60 \mathrm{ab}$ \\
Testemunha & $3,02 \pm 4,11 \mathrm{~b}$ & $12,65 \pm 10,41$ a & $15,29 \pm 13,28$ b \\
\hline
\end{tabular}

${ }^{1}$ Médias seguidas de mesma letra, nas colunas, não diferem entre si, pelo teste de Tukey $(P \leq 0,05)$. 
Tabela 2. Médias ( \pm EP) de duração das fases de ovo, ninfa e ovo-adulto de Bemisia tabaci biótipo $\mathrm{B}$, em tomateiro, após aplicação de extratos aquosos de Trichilia pallida e Melia azedarach sobre os ovos. Temp.: $18,4 \pm 6,7^{\circ} \mathrm{C}$; UR: $72,4 \pm 21,9 \%$; fotoperíodo natural.

\begin{tabular}{lccc}
\hline Extratos & \multicolumn{3}{c}{ Duração (dias) $^{1}$} \\
\cline { 2 - 4 } & Ovo & Ninfa & Ovo-adulto \\
\hline M. azedarach 2\% & $7,48 \pm 0,32$ & $21,22 \pm 0,25$ & $28,70 \pm 0,41$ \\
M. azedarach 1\% & $7,48 \pm 0,35$ & $21,22 \pm 0,24$ & $28,70 \pm 0,55$ \\
T. pallida 2\% & $7,89 \pm 0,08$ & $21,24 \pm 0,23$ & $29,13 \pm 0,20$ \\
T. pallida 1\% & $7,94 \pm 0,03$ & $21,00 \pm 0,15$ & $28,94 \pm 0,14$ \\
Testemunha & $7,43 \pm 0,20$ & $20,97 \pm 0,25$ & $28,40 \pm 0,41$ \\
\hline
\end{tabular}

${ }^{1}$ Médias, nas colunas, não diferem entre si, pelo teste de Tukey $(P \leq 0,05)$. 


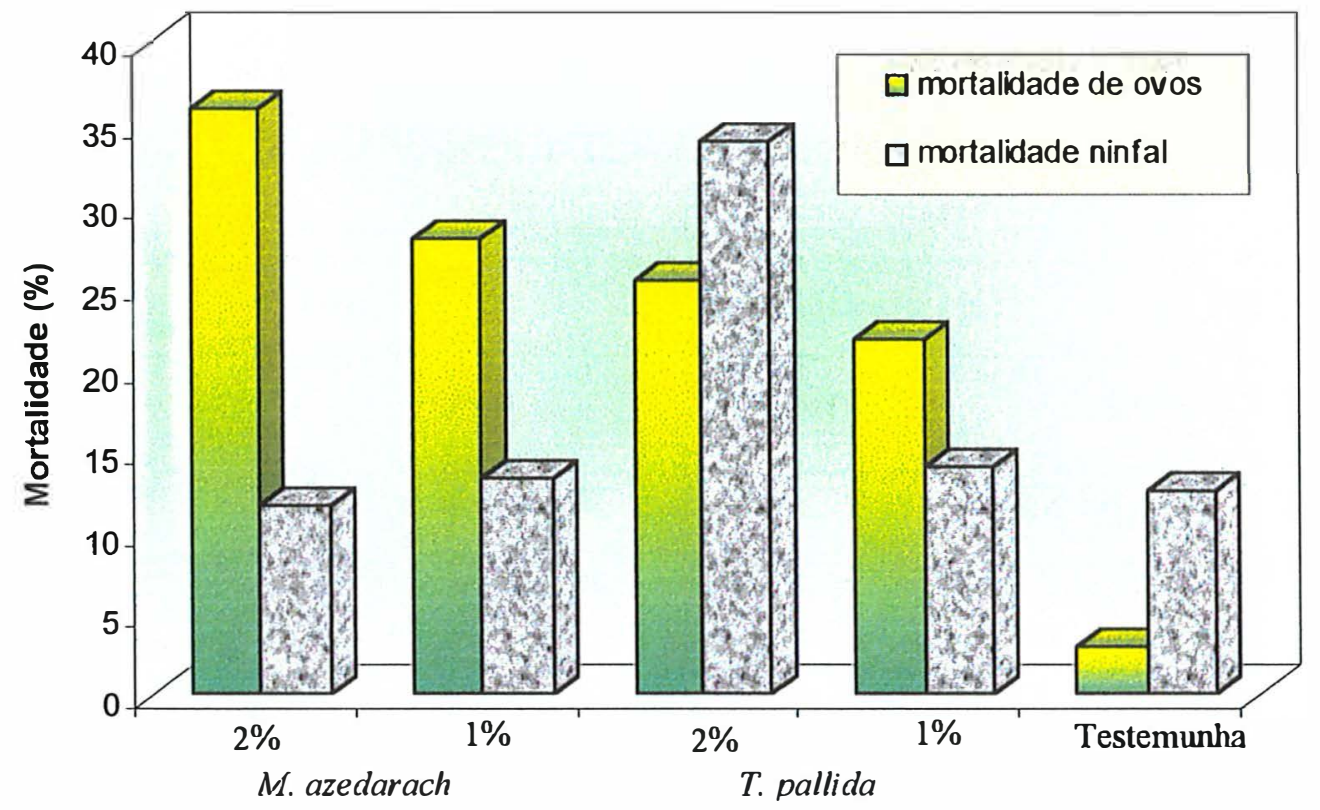

Figura 2. Médias de mortalidade das fases de ovo, ninfa e ovo-adulto de Bemisia tabaci biótipo $\mathrm{B}$, em tomateiro, após aplicação de extratos aquosos de meliáceas sobre os ovos. Temp.: $18,4 \pm 6,7^{\circ} \mathrm{C}$; UR: 72,4 $\pm 21,9 \%$; fotoperíodo natural. 
Tabela 3. Médias ( \pm EP) de mortalidade das fases de ovo, ninfa e ovo-adulto de Bemisia tabaci biótipo $\mathrm{B}$, em tomateiro, após aplicação de extratos aquosos de Trichilia pallida e Melia azedarach sobre os ovos. Temp.: $16,6 \pm 9,7^{\circ} \mathrm{C}$; UR: $80,6 \pm 22,4 \%$; fotoperíodo natural.

\begin{tabular}{|c|c|c|c|}
\hline \multirow{2}{*}{ Extratos } & \multicolumn{3}{|c|}{ Mortalidade (\%) ${ }^{1}$} \\
\hline & Ovo & Ninfa & Ovo-adulto \\
\hline M. azedarach 3\% & $32,61 \pm 23,99 a b$ & $29,96 \pm 6,96 a$ & $52,80 \pm 16,73 a b$ \\
\hline M. azedarach $2 \%$ & $18,40 \pm 14,45$ bc & $9,40 \pm 13,84 a$ & $26,07 \pm 22,38 \quad b c$ \\
\hline M. azedarach $1 \%$ & $17,60 \pm 6,03 b c$ & $22,39 \pm 6,27 a$ & $36,05 \pm 7,82 a b c$ \\
\hline T. pallida 3\% & $52,82 \pm 14,00 a$ & $17,59 \pm 7,43 a$ & $61,11 \pm 9,53 a$ \\
\hline T. pallida $2 \%$ & $37,33 \pm 8,64 a b$ & $30,66 \pm 14,51 \mathrm{a}$ & $56,54 \pm 14,23 a b$ \\
\hline T. pallida $1 \%$ & $16,46 \pm 6,59 \mathrm{bc}$ & $22,28 \pm 9,99 a$ & $35,07 \pm 11,52 a b c$ \\
\hline Testemunha & $1,04 \pm 1,20$ & $18,03 \pm 12,17 a$ & $18,88 \pm 12,90$ \\
\hline
\end{tabular}

${ }^{1}$ Médias seguidas de mesma letra, nas colunas, não diferem entre si, pelo teste de Tukey $(P \leq 0,05)$. 
Tabela 4. Médias ( \pm EP) de duração das fases de ovo, ninfa e ovo-adulto de Bemisia tabaci biótipo B em tomateiro após aplicação de extratos aquosos de Trichilia pallida e Melia azedarach sobre os ovos. Temp.: $16,6 \pm 9,7^{\circ} \mathrm{C}$; UR: $80,6 \pm 22,4 \%$; fotoperiodo natural.

\begin{tabular}{lccc}
\hline \multirow{2}{*}{ Extratos } & \multicolumn{3}{c}{ Duração (dias) $^{1}$} \\
\cline { 2 - 4 } & Ovo & Ninfa & Ovo-adulto \\
\hline M. azedarach 3\% & $12,56 \pm 0,56$ a & $24,88 \pm 0,25 \mathrm{ab}$ & $37,44 \pm 0,62 \mathrm{a}$ \\
M. azedarach 2\% & $12,51 \pm 0,15 \mathrm{a}$ & $24,88 \pm 0,36 \mathrm{ab}$ & $37,39 \pm 0,46 \mathrm{a}$ \\
M. azedarach 1\% & $12,61 \pm 0,18$ a & $24,69 \pm 0,35 \mathrm{~b}$ & $37,30 \pm 0,36 \mathrm{a}$ \\
T. pallida 3\% & $13,02 \pm 0,25 \mathrm{a}$ & $25,28 \pm 0,35 \mathrm{ab}$ & $38,30 \pm 0,56 \mathrm{a}$ \\
T. pallida 2\% & $12,74 \pm 0,28$ a & $25,33 \pm 0,12 \mathrm{ab}$ & $38,07 \pm 0,40 \mathrm{a}$ \\
T. pallida 1\% & $12,75 \pm 0,15 \mathrm{a}$ & $24,87 \pm 0,40 \mathrm{ab}$ & $37,62 \pm 0,55 \mathrm{a}$ \\
Testemunha & $12,80 \pm 0,15$ a & $25,53 \pm 0,46 \mathrm{a}$ & $38,33 \pm 0,55 \mathrm{a}$ \\
\hline
\end{tabular}

${ }^{1}$ Médias seguidas de mesma letra, nas colunas, não diferem entre si, pelo teste de Tukey $(P \leq 0,05)$. 


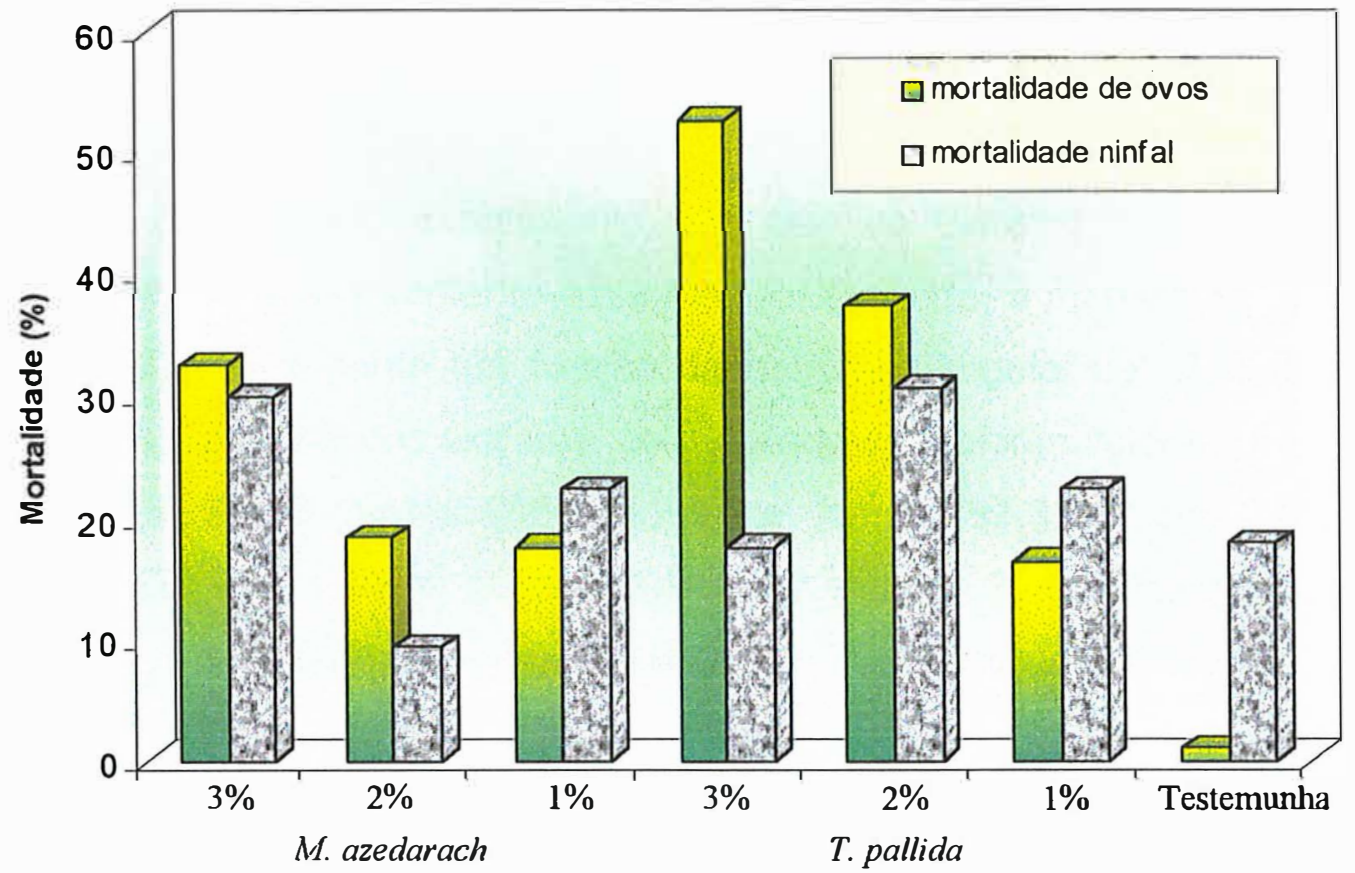

Figura 3. Médias de mortalidade das fases de ovo, ninfa e ovo-adulto de Bemisia tabaci biótipo $\mathrm{B}$, em tomateiro, após aplicação de extratos aquosos de meliáceas sobre os ovos. Temp.: $16,6 \pm 9,7^{\circ} \mathrm{C}$; UR: 80,6 $\pm 22,4 \%$; fotoperíodo natural. 
4.2 Seleção das estruturas vegetais de $M$. azedarach e de $T$. pallida mais efetivas, na forma de extrato aquoso, em relação a $B$. tabaci biótipo $B$

\subsubsection{Experimentos com $M$. azedarach}

No primeiro experimento, em que os extratos foram aplicados apenas sobre os ovos e somente essa fase foi avaliada, a mortalidade (Tabela 5) diferiu significativamente em função da estrutura vegetal de $M$. azedarach utilizada para o preparo dos extratos, constatando-se maiores valores com o uso de extrato de frutos verdes $(58,04 \%)$ e de folhas $(47,35 \%)$ em relação à testemunha (2,68\%). Apesar da mortalidade ter atingido $36,63 \%$ com extrato de frutos maduros e $35,80 \%$ com extrato de ramos, não houve diferença estatística desses valores em relação ao obtido na testemunha.

O período de incubação nos tratamentos com extrato de frutos verdes $(8,42$ dias) e de ramos ( 8,11 dias) foi maior que o registrado com extrato de folhas (7,02 dias) sendo a diferença estatística encontrada apenas entre esses valores (Tabela 5).

No segundo experimento, em que os extratos foram aplicados inicialmente sobre os ovos e posteriormente sobre ninfas com três dias e no qual a avaliação do inseto foi acompanhada até a emergência do adulto, verificou-se que a mortalidade durante a fase de ovo foi maior nos extratos de folhas e de frutos verdes $(34,95$ e $31,13 \%$, respectivamente) que na testemunha $(3,06 \%)$, confirmando a maior atividade inseticida dessas estruturas vegetais. Os extratos de ramos e frutos maduros proporcionaram valores de mortalidade de 18,25 e $12,21 \%$, respectivamente, e, de modo análogo ao verificado no experimento anterior, não diferiram da testemunha (Tabela 6).

A sobrevivência ninfal também foi afetada pelo uso dos extratos, constatando-se maior efeito com extrato de frutos verdes, seguindo-se os tratamentos com extrato de frutos maduros e de folhas onde os valores de mortalidade $(55,15 ; 39,10$ e $35,34 \%$, respectivamente) não diferiram entre si mas 
foram superiores ao valor encontrado na testemunha $(7,48 \%)$. No tratamento com extrato de ramos, embora a mortalidade ninfal tenha sido aparentemente maior $(22,91 \%)$ que a verificada na testemunha, não houve diferença significativa entre as médias.

Considerando-se a fase ovo-adulto, todas as estruturas vegetais testadas foram eficientes provocando mortalidades superiores $(37,40$ a $69,11 \%)$ à registrada na testemunha $(10,43 \%)$. Os extratos mais eficientes foram os preparados com frutos verdes $(69,11 \%)$ e folhas $(57,94 \%)$ que diferiram do extrato de ramos $(37,40 \%)$, registrando-se com extrato de frutos maduros um valor de mortalidade intermediário (Tabela 6).

Embora os valores de mortalidade de ovos e ninfas não tenham sido comparados estatisticamente entre si, verifica-se que, com a aplicação dos extratos de frutos verdes e de frutos maduros de $M$. azedarach sobre as ninfas, houve uma tendência de maior mortalidade destas que dos ovos quando apenas estes foram tratados (Tabela 6 e Figura 4). Considerando-se, por outro lado, que nos experimentos discutidos no item 4.1, foi constatado que extratos aplicados sobre ovos não afetam sobrevivência das ninfas, pode-se inferir que a mortalidade ninfal verificada no presente experimento foi devida apenas à aplicação dos extratos sobre as ninfas. Isso permite concluir que, ao menos em relação a essas duas estruturas vegetais, a fase de ovo é mais resistente à ação dos extratos que a de ninfa.

O período de incubação não foi afetado pelos tratamentos, variando de 7,36 a 7,56 dias (Tabela 7). Em relação à duração da fase ninfal, entretanto, embora os valores tenham sido bastante próximos, com amplitude máxima de 0,45 dias, houve diferença significativa entre os valores extremos (16,34 dias com extrato de frutos verdes e 15,89 dias com extrato de frutos maduros, constatando-se nos demais tratamentos (incluindo a testemunha) valores intermediários (Tabela 7). Este alongamento refletiu-se no periodo ovoadulto que também foi maior no tratamento com extrato de frutos verdes que naquele com frutos maduros (23,90 e 23,32 dias, respectivamente), com valores 
intermediários nos demais tratamentos (Tabela 7).

Considerando-se os dois experimentos, concluiu-se que os frutos verdes foram a estrutura vegetal de $M$. azedarach mais eficiente contra $B$. tabaci biótipo $B$, sendo então selecionada para utilização nos testes seguintes.

Tabela 5. Médias ( \pm EP) de mortalidade e duração da fase de ovo de Bemisia tabaci biótipo $\mathrm{B}$, em tomateiro, após aplicação de extratos aquosos de diferentes estruturas vegetais de Melia azedarach sobre os ovos. Temp.: $20,6 \pm 7,6^{\circ} \mathrm{C}$; UR: $70,1 \pm 13,7 \%$; fotoperiodo natural.

\begin{tabular}{lcc}
\hline Extratos & Mortalidade (\%) $^{\mathbf{1}}$ & Duração (dias) $^{\mathbf{1}}$ \\
\hline Frutos verdes & $58,04 \pm 10,78 \mathrm{a}$ & $8,42 \pm 0,14 \mathrm{a}$ \\
Folhas & $47,35 \pm 15,65 \mathrm{a}$ & $7,02 \pm 0,15 \mathrm{~b}$ \\
Frutos maduros & $36,63 \pm 21,10 \mathrm{ab}$ & $7,87 \pm 0,08 \mathrm{ab}$ \\
Ramos & $35,80 \pm 20,24 \mathrm{ab}$ & $8,11 \pm 0,86 \mathrm{a}$ \\
Testemunha & $2,68 \pm 3,11 \mathrm{~b}$ & $7,54 \pm 0,58 \mathrm{ab}$ \\
\hline
\end{tabular}

${ }^{1}$ Médias seguidas de mesma letra, nas colunas, não diferem entre si, pelo teste de Tukey $(P \leq 0,05)$. 
Tabela 6. Médias ( \pm EP) de mortalidade das fases de ovo, ninfa e ovo-adulto de Bemisia tabaci biótipo $\mathrm{B}$, em tomateiro, após aplicação de extratos aquosos de diferentes estruturas vegetais de Melia azedarach sobre ovos e ninfas. Temp.: $20,8 \pm 6,0^{\circ} \mathrm{C}$; UR: $65,5 \pm 17,6 \%$; fotoperíodo natural.

\begin{tabular}{lcccc}
\hline \multirow{2}{*}{ Extratos } & \multicolumn{4}{c}{ Mortalidade (\%) $^{\mathbf{1}}$} \\
\cline { 2 - 5 } & \multicolumn{2}{c}{ Ovo } & Ninfa & Ovo-adulto \\
\hline Folhas & $34,95 \pm 9,89 \mathrm{a}$ & $35,34 \pm 5,89 \mathrm{ab}$ & $57,94 \pm 2,88 \mathrm{ab}$ \\
Frutos verdes & $31,13 \pm 5,10 \mathrm{ab}$ & $55,15 \pm 18,32 \mathrm{a}$ & $69,11 \pm 12,99 \mathrm{a}$ \\
Ramos & $18,25 \pm 7,96 \mathrm{abc}$ & $22,91 \pm 13,08$ bc & $37,40 \pm 8,49 \quad \mathrm{c}$ \\
Frutos maduros & $12,21 \pm 14,58$ bc & $39,10 \pm 5,10 \mathrm{ab}$ & $46,60 \pm 9,44$ bc \\
Testemunha & $3,06 \pm 3,76$ c & $7,48 \pm 8,68$ c & $10,43 \pm 7,50 \quad$ d \\
\hline
\end{tabular}

${ }^{1}$ Médias seguidas de mesma letra, nas colunas, não diferem entre si, pelo teste de Tukey $(P \leq 0,05)$. 
Tabela 7. Médias ( \pm EP) de duração das fases de ovo, ninfa e ovo-adulto de Bemisia tabaci biótipo $\mathrm{B}$, em tomateiro, após aplicação de extratos aquosos de Melia azedarach sobre ovos e ninfas. Temp.: 20,8 \pm $6,0^{\circ} \mathrm{C}$; UR: $65,5 \pm 17,6 \%$; fotoperíodo natural.

\begin{tabular}{lccc}
\hline \multirow{2}{*}{ Extratos } & \multicolumn{3}{c}{ Duração (dias) $^{1}$} \\
\cline { 2 - 4 } & Ovo & Ninfa & Ovo-adulto \\
\hline Frutos verdes & $7,56 \pm 0,12 \mathrm{a}$ & $16,34 \pm 0,16 \mathrm{a}$ & $23,90 \pm 0,11 \mathrm{a}$ \\
Frutos maduros & $7,43 \pm 0,19 \mathrm{a}$ & $15,89 \pm 0,14 \mathrm{~b}$ & $23,32 \pm 0,26 \mathrm{~b}$ \\
Ramos & $7,42 \pm 0,11 \mathrm{a}$ & $16,07 \pm 0,11 \mathrm{ab}$ & $23,49 \pm 0,02 \mathrm{ab}$ \\
Folhas & $7,36 \pm 0,06 \mathrm{a}$ & $16,13 \pm 0,13 \mathrm{ab}$ & $23,49 \pm 0,11 \mathrm{ab}$ \\
Testemunha & $7,41 \pm 0,25 \mathrm{a}$ & $16,05 \pm 0,20 \mathrm{ab}$ & $23,46 \pm 0,45 \mathrm{ab}$ \\
\hline
\end{tabular}

${ }^{1}$ Médias seguidas de mesma letra, nas colunas, não diferem entre si, pelo teste de Tukey $(P \leq 0,05)$. 


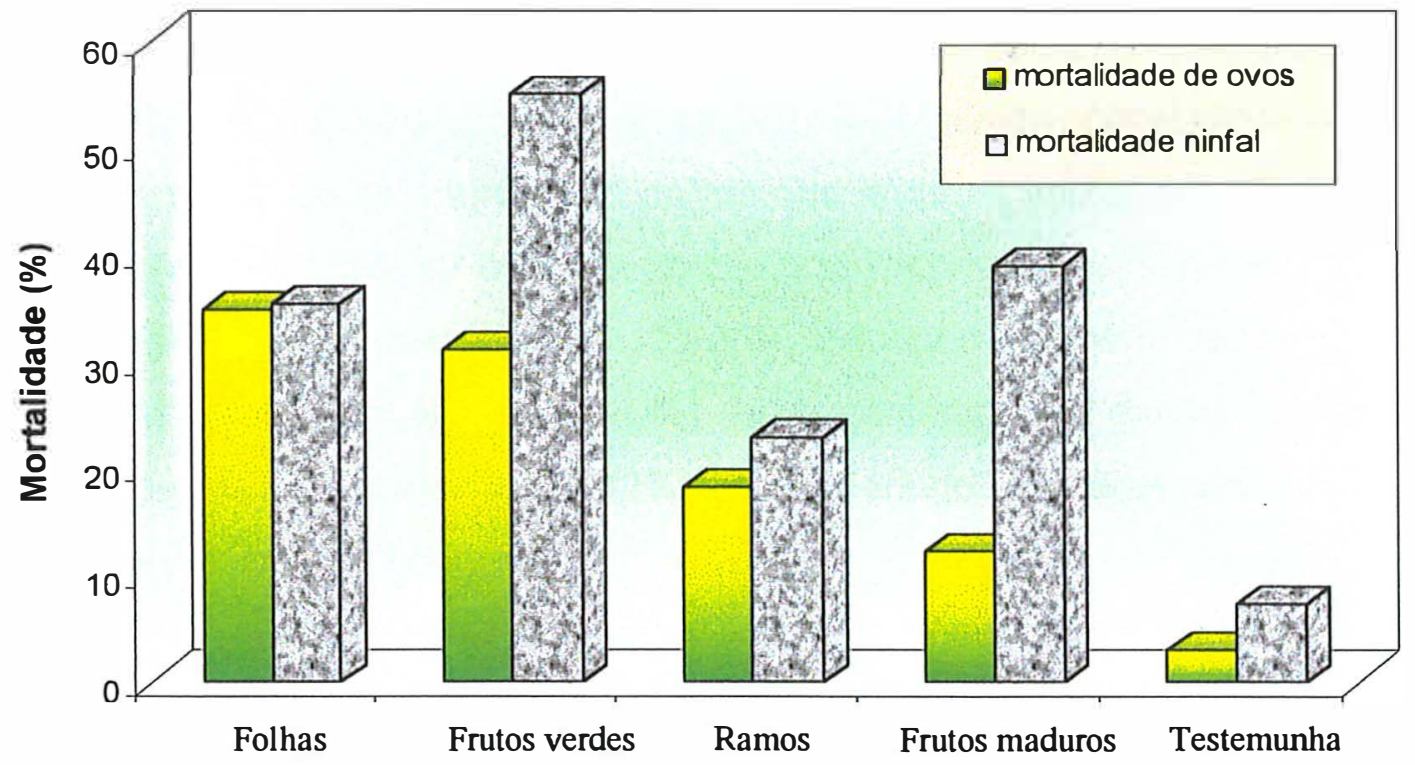

Figura 4. Médias de mortalidade das fases de ovo, ninfa e ovo-adulto de Bemisia tabaci biótipo $\mathrm{B}$, em tomateiro, após a aplicação de extratos aquosos de Melia azedarach sobre ovos e ninfas. Temp.: 20,8 \pm $6,0^{\circ} \mathrm{C}$; UR: $65,5 \pm 17,6 \%$; fotoperíodo natural. 


\subsubsection{Experimentos com T. pallida}

No primeiro experimento, em que os extratos foram aplicados apenas sobre os ovos e somente essa fase foi avaliada, constatou-se que os ramos foram a única estrutura de $T$. pallida que afetou a sobrevivência da mosca branca durante a fase de ovo, proporcionando mortalidade superior $(51,22 \%)$ que a registrada na testemunha $(2,98 \%)$, diferindo também da mortalidade obtida com extrato de córtex (17,54 \%). No tratamento com extrato de folhas, a mortalidade foi intermediária $(25,42 \%)$, não diferindo daquelas registradas nos demais tratamentos (Tabela 8 ).

O período de incubação, por outro lado, não foi afetado pelos extratos, registrando-se variação bastante reduzida (7,15 a 7,45 dias) nos diversos tratamentos (Tabela 8).

No segundo experimento, em que, além dos ovos, também as ninfas com três dias receberam aplicação de extrato, e no qual a avaliação foi feita até a emergência do adulto, o maior efeito sobre a viabilidade dos ovos, ocorreu, de modo semelhante ao que foi registrado no experimento anterior, com o emprego de extrato de ramos, no qual a mortalidade foi significativamente superior $(41,39 \%)$ àquela obtida na testemunha $(11,25 \%)$ e com uso do extrato de córtex $(16,36 \%)$; com extrato de folhas, observou-se valor intermediário $(28,79 \%)$ (Tabela 9 e Figura 5).

A sobrevivência ninfal também foi afetada pelo extrato de ramos que provocou mortalidade de $43,32 \%$, valor significativamente superior aos registrados na testemunha $(19,01 \%)$ e com extrato de córtex $(27,90 \%)$, observando-se novamente valor intermediário $(32,14 \%)$ com uso do extrato de folhas (Tabela 9).

Diferentemente do que ocorreu com frutos verdes e frutos maduros de $M$. azedarach que foram mais efetivos sobre as ninfas que sobre os ovos, no caso de $T$. pallida, as estruturas testadas apresentaram efeito similar sobre as duas fases do inseto (Tabela 9 e Figura 5). 
Considerando-se toda a fase imatura, a maior eficiência foi, uma vez mais, encontrada com o extrato de ramos seguindo-se o extrato de folhas (mortalidades de 66,78 e 51,68\%, respectivamente), diferindo ambos do valor obtido na testemunha $(28,12 \%)$; com extrato de córtex, registrou-se mortalidade intermediária $(39,69 \%)$ diferindo apenas da registrada no tratamento mais efetivo. O extrato de folhas, que não provocou efeito significativo em comparação com a testemunha quando as fases de ovo e ninfa foram consideradas separadamente, passou a apresentar média significativamente superior quando as mortalidades nessas fases foram consideradas de modo cumulativo, continuando, no entanto, em posição intermediária quando comparado aos extratos de ramos e córtex (Tabela 9).

O valor registrado na testemunha (ovos não tratados) para a viabilidade da fase ovo-adulto $(71,88 \%)$ é superior ao registrado por Tsai \& Wang (1996) que encontraram na mesma planta hospedeira e em temperatura levemente inferior viabilidade de $60,2 \%$. Em relação à viabilidade dos ovos, os valores estão próximos $(88,75 \%$ na presente pesquisa e $96,0 \%$ no trabalho de Tsai \& Wang (1996).

A duração das fases de ovo, ninfa e ovo-adulto não foi afetada pelos extratos, constatando-se para o primeiro parâmetro valor de 7,00 dias para todas as repetições dos quatro tratamentos, enquanto para os demais os valores variaram de 12,72 a 12,86 dias e de 19,72 a 19,86 dias, respectivamente (Tabela 10). Estes valores estão próximos dos registrados por Tsai \& Wang (1996) (6,21 dias para o período de incubação e 11,75 dias para a fase ninfal), em condições similares de ambiente e na mesma planta hospedeira.

Os menores valores observados para a duração da fase de ovo e principalmente para a duração da fase ninfal no experimento com $T$. pallida (Tabela 10) em relação aos registrados naquele com $M$. azedarach (Tabela 7) provavelmente tenham sido resultantes do aumento da temperatura na casa de vegetação, que oscilou, em média, de $20,8^{\circ} \mathrm{C}$ para $26,1^{\circ} \mathrm{C}$, do primeiro para o segundo experimento. Conforme foi mencionado anteriormente, ocorre redução 
no período de desenvolvimento de $B$. tabaci biótipo B com o aumento de temperatura na faixa de 15 a $30^{\circ} \mathrm{C}$ (Enkegaard, 1993; Wagner, 1995 e Wang e Tsai, 1996).

A partir dos resultados obtidos nesses dois experimentos, concluiuse que os ramos são a estrutura de $T$. pallida mais efetiva no controle de mosca branca, tendo, em função disso, sido selecionada para os experimentos seguintes.

Tabela 8. Médias ( \pm EP) de mortalidade e duração da fase de ovo de Bemisia tabaci biótipo $\mathrm{B}$, em tomateiro, após aplicação de extratos aquosos de diferentes estruturas vegetais de Trichilia pallida sobre os ovos. Temp.: $20,7 \pm 6,0^{\circ} \mathrm{C}$; UR: $70,0 \pm 17,6 \%$; fotoperíodo natural.

\begin{tabular}{lcc}
\hline Extratos & Mortalidade (\%) $^{1}$ & Duração (dias) $^{\mathbf{1}}$ \\
\hline Ramos & $51,22 \pm 11,68 \mathrm{a}$ & $7,22 \pm 0,28 \mathrm{a}$ \\
Folhas & $25,42 \pm 19,31 \mathrm{ab}$ & $7,34 \pm 0,30 \mathrm{a}$ \\
Córtex & $17,54 \pm 11,50 \mathrm{~b}$ & $7,15 \pm 0,24 \mathrm{a}$ \\
Testemunha & $2,98 \pm 4,13 \mathrm{~b}$ & $7,45 \pm 0,23 \mathrm{a}$ \\
\hline
\end{tabular}

${ }^{1}$ Médias seguidas de mesma letra, nas colunas, não diferem entre si, pelo teste de Tukey $(P \leq 0,05)$. 
Tabela 9. Médias $( \pm$ EP) de mortalidade das fases de ovo, ninfa e ovo-adulto de Bemisia tabaci biótipo $\mathrm{B}$, em tomateiro, após aplicação de extratos aquosos de diferentes estruturas vegetais de Trichilia pallida sobre ovos e ninfas. Temp.: 26,1 $\pm 5,0^{\circ} \mathrm{C}$; UR: $65,0 \pm 15,6 \%$; fotoperíodo natural.

\begin{tabular}{|c|c|c|c|}
\hline \multirow{2}{*}{ Extratos } & \multicolumn{3}{|c|}{ Mortalidade $(\%)^{1}$} \\
\hline & Ovo & Ninfa & Ovo-adulto \\
\hline Ramos & $41,39 \pm 2,63 a$ & $43,32 \pm 11,54 a$ & $66,78 \pm 6,42 a$ \\
\hline Folhas & $28,79 \pm 9,54 a b$ & $32,14 \pm 4,51 \mathrm{ab}$ & $51,68 \pm 3,99 a b$ \\
\hline Córtex & $16,36 \pm 15,55 \quad b$ & $27,90 \pm 5,16 \quad b$ & $39,69 \pm 13,55 b c$ \\
\hline Testemunha & $11,25 \pm 2,66 \quad b$ & $19,01 \pm 2,44 \quad b$ & $28,12 \pm 2,16$ \\
\hline
\end{tabular}

${ }^{1}$ Médias seguidas de mesma letra, nas colunas, não diferem entre si, pelo teste de Tukey $(P \leq 0,05)$. 
Tabela 10. Médias ( \pm EP) de duração das fases de ovo, ninfa e ovo-adulto de Bemisia tabaci biótipo B em tomateiro após aplicação de extratos aquosos de Trichilia pallida sobre ovos e ninfas. Temp.: $26,1 \pm 5,0^{\circ} \mathrm{C}$; UR: $65,0 \pm 15,6 \%$; fotoperíodo natural.

\begin{tabular}{lccc}
\hline \multirow{2}{*}{ Extratos } & \multicolumn{3}{c}{ Duração (dias) } \\
\cline { 2 - 4 } & Ovo $^{1}$ & Ninfa $^{2}$ & Ovo adulto $^{2}$ \\
& & & \\
\hline Ramos & $7,00 \pm 0,00$ & $12,75 \pm 0,08$ & $19,75 \pm 0,08$ \\
Córtex & $7,00 \pm 0,00$ & $12,74 \pm 0,03$ & $19,74 \pm 0,03$ \\
Folhas & $7,00 \pm 0,00$ & $12,72 \pm 0,11$ & $19,72 \pm 0,11$ \\
Testemunha & $7,00 \pm 0,00$ & $12,86 \pm 0,12$ & $19,86 \pm 0,12$ \\
\hline
\end{tabular}

${ }^{1}$ Dados não analisados estatisticamente

${ }^{2}$ Médias, nas colunas, não diferem entre si, pelo teste de Tukey $(P \leq 0,05)$. 


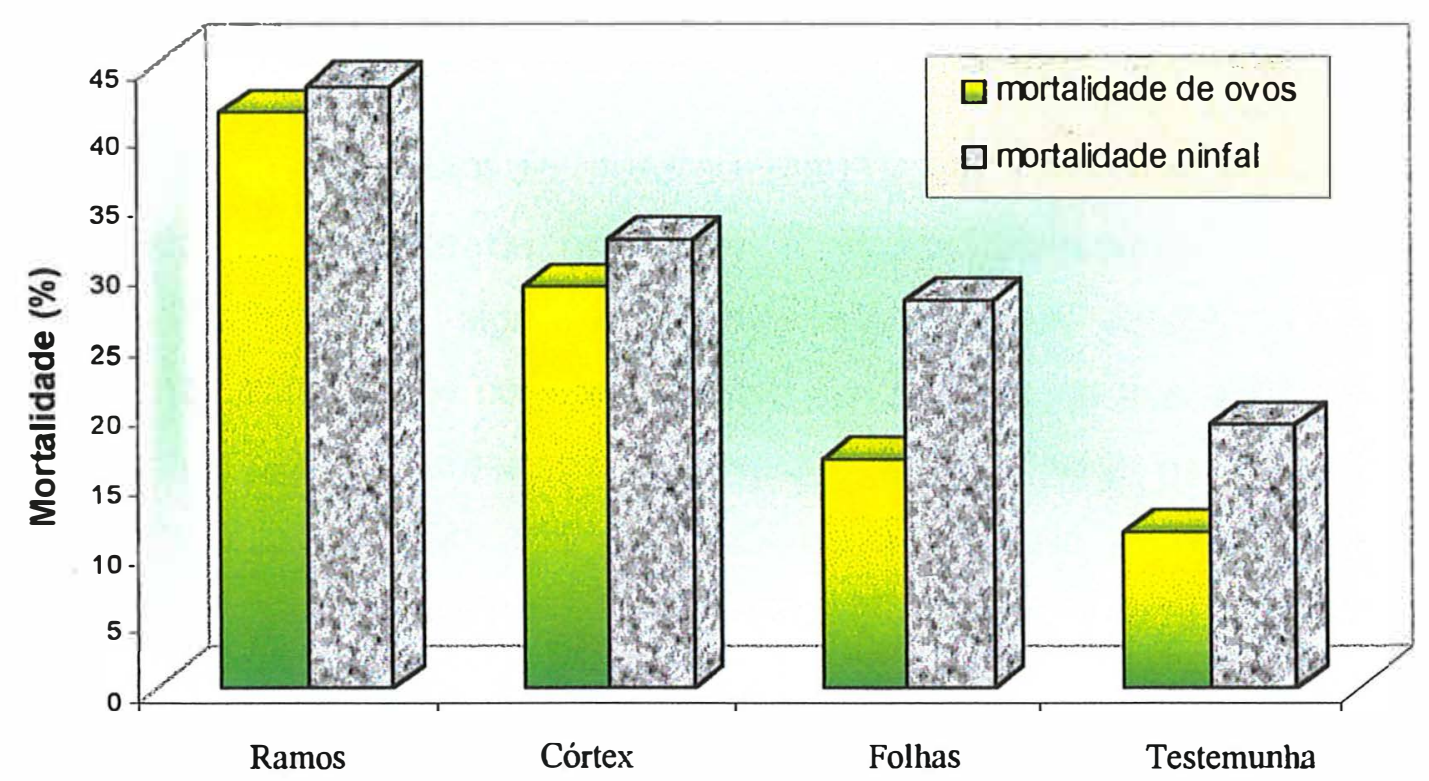

Figura 5. Médias de mortalidade das fases de ovo, ninfa e ovo-adulto de Bemisia tabaci biótipo $\mathrm{B}$, em tomateiro, após aplicação de extratos aquosos de Trichilia pallida sobre ovos e ninfas. Temp.: $26,1 \pm 5,0^{\circ} \mathrm{C}$; UR: $65,0 \pm 15,6 \%$; fotoperíodo natural. 


\subsection{Efeito de extratos aquosos de três meliáceas sobre a biologia de $B$. tabaci biótipo B}

\subsubsection{Primeiro experimento}

No que se refere ao efeito ovicida (Tabela 11), a maior eficiência foi encontrada com extrato de ramos de $T$. pallida, tratamento em que a mortalidade $(38,65 \%)$ foi significativamente superior em relação àquelas observadas nos tratamentos correspondentes aos extratos de frutos verdes de M. azedarach e de sementes de Azadirachta indica (nim), os quais não diferiram entre si provocando 28,91 e $31,31 \%$ de mortalidade, respectivamente. Em comparação à testemunha, onde a mortalidade atingiu apenas $2,15 \%$, os três tratamentos foram eficientes.

O efeito sobre as ninfas (Tabela 11), por outro lado, foi bastante acentuado com o emprego do extrato de sementes de nim, que provocou mortalidade de $86,57 \%$, diferindo de todos os outros tratamentos. Num segundo grupo, situaram-se os tratamentos à base de frutos verdes de $M$. azedarach e de ramos de $T$. pallida, nos quais os valores de mortalidade $(54,86$ e $53,61 \%$, respectivamente) também diferiram estatisticamente do valor encontrado na testemunha $(12,83 \%)$.

Observando-se os valores de mortalidade de ovos e ninfas, embora novamente os mesmas não tenham sido comparados estatisticamente entre si, constata-se, a exemplo do que foi verificado com frutos verdes e frutos maduros de $M$. azedarach, que aparentemente a mortalidade foi maior na fase de ninfa que na fase de ovo, com os três extratos testados (Tabela 12 e Figura $6)$.

Considerando os dados acumulados das fases de ovo e de ninfa, os resultados foram bastante similares aos obtidos com a fase ninfal isoladamente, com maior mortalidade com extrato de $A$. indica $(90,98 \%)$, que diferiu dos resultados obtidos com os extratos de $T$. pallida e de $M$. azedarach 
(71,49 e $67,73 \%$, respectivamente), os quais também diferiram do valor observado na testemunha $(14,73 \%)$ (Tabela 11$)$. Os resultados demonstram que os extratos de $T$. pallida e $M$. azedarach afetaram de modo semelhante a sobrevivência das ninfas de mosca branca e nenhum deles foi tão efetivo quanto o extrato de nim.

Comparando-se os dados obtidos na testemunha com os registrados por Tsai \& Wang (1996), em condições semelhantes de temperatura e na mesma planta hospedeira, verifica-se que o valor encontrado na presente pesquisa para a viabilidade da fase ovo-adulto $(85,27 \%)$ é superior ao registrado por aqueles autores $(60,2 \%)$, havendo similaridade quanto aos dados de viabilidade dos ovos (97,85 e 96,0\%, respectivamente).

As durações dos períodos de incubação (6,57 a 6,70 dias), ninfal (12,89 a 12,98 dias) e ovo-adulto (19,50 a 19,66 dias) não diferiram estatisticamente nos diversos tratamentos, incluindo a testemunha (Tabela 12) e estão próximos dos obtidos por Tsai \& Wang (1996), em condições similares de ambiente e na mesma planta hospedeira.

\subsubsection{Segundo experimento}

Os três extratos aplicados apenas sobre as ninfas com três dias de idade foram eficientes para controle dessa fase, quando comparados à testemunha. O extrato mais eficiente foi aquele à base de sementes de nim, no qual a mortalidade atingiu $89,79 \%$, sendo superior às constatadas com os extratos de $M$. azedarach e T. pallida (68,66 e 64,91\%, respectivamente). Para os três extratos, a mortalidade diferiu daquela registrada na testemunha $(19,19 \%)$ (Tabela 13).

Comparando-se os resultados obtidos nesse experimento em que apenas as ninfas receberam aplicação dos extratos, com o experimento anterior, 
em que tanto os ovos como as ninfas foram tratados, verifica-se que as mortalidades na fase ninfal foram semelhantes, já que os valores aparentemente superiores nos tratamentos com extratos no segundo experimento também foram observados na testemunha (Tabelas 11 e 13 e Figuras 6 e 7). Esses dados vem confirmar os resultados discutidos anteriormente que evidenciaram que a aplicação dos extratos sobre ovos não afeta a sobrevivência ninfal.

A longevidade dos adultos (Tabela 13) foi afetada de modo diferenciado em função do sexo. Para os machos, os valores de longevidade não diferiram significativamente variando entre 7,30 e 10,92 dias para os vários tratamentos, incluindo a testemunha. Já para as fêmeas, houve diferença entre os tratamentos, verificando-se que os adultos provenientes de ninfas tratadas com $A$. indica foram mais longevos (12,04 dias) que os oriundos dos tratamentos com $T$. pallida (7,67 dias) e com $M$. azedarach (9,27dias), ocorrendo um valor intermediário na testemunha.

Tendência semelhante foi constatada com a fecundidade já que novamente os adultos provenientes do tratamento com nim apresentaram melhor desempenho (23,77 ovos/fêmea), diferindo, nesse caso, apenas daqueles oriundos do tratamento com $M$. azedarach (13,88 ovos/fêmea); no tratamento com $T$. pallida e na testemunha foram obtidos valores intermediários. Entretanto, considerando-se o número diário de ovos por fêmea, não houve diferença entre os tratamentos, com valores variando entre 1,50 e 2,04 (Tabela 14), o que indica que o maior número de ovos depositados por fêmea no tratamento com nim está associado ao maior tempo de oviposição (Tabelas 13 e 14).

Os valores de longevidade das fêmeas (9,99 dias) e fecundidade (18,70 ovos/fêmea) obtidos nas plantas não tratadas, na presente pesquisa, foram baixos quando comparados aos registrados por Tsai \& Wang (1996) (20,55 dias e 167,55 ovos por fêmea), em condições próximas de temperatura e na mesma planta hospedeira.

Em princípio, não foi encontrada uma razão para explicar o melhor 
desempenho dos adultos provenientes do tratamento com extrato de $A$. indica. A seleção natural que poderia ter sido provocada pelo efeito drástico do referido extrato sobre as ninfas, o que poderia levar à sobrevivência de indivíduos comparativamente mais vigorosos, não poderia justificar esse fato porque se isso tivesse ocorrido, as diferenças seriam encontradas em relação à testemunha, onde foi constatada baixa mortalidade ninfal e não em relação aos demais tratamentos com extratos onde as mortalidades foram mais próximas da constatada com extrato de nim (Tabela 14).

Tabela 11. Médias ( \pm EP) de mortalidade das fases de ovo, ninfa e ovo-adulto de Bemisia tabaci biótipo $B$, em tomateiro, após aplicação de extratos aquosos de meliáceas sobre ovos e ninfas. Temp.: 25,5 \pm $4,6^{\circ} \mathrm{C}$; UR: $65,3 \pm 13,7 \%$; fotoperíodo natural.

\section{Extratos}

Mortalidade (\%) ${ }^{1}$

\begin{tabular}{|c|c|c|c|}
\hline & \\
\hline & Ovo & Ninfa & Ovo-adulto \\
\hline T. pallida (ramos) & $38,65 \pm 0,97 a$ & $53,61 \pm 8,57 b$ & b $71,49 \pm 5,65 b$ \\
\hline A. indica (sementes) & $31,31 \pm 3,72 b$ & $86,57 \pm 7,01 \mathrm{a}$ & $90,98 \pm 4,23 a$ \\
\hline M. azedarach (frutos verdes) & $28,91 \pm 3,26 b$ & $54,86 \pm 9,54 b$ & b $67,73 \pm 8,07 b$ \\
\hline Testemunha & $2,15 \pm 1,16 \quad c$ & $12,83 \pm 8,32$ & c $14,73 \pm 7,91$ c \\
\hline
\end{tabular}

${ }^{1}$ Médias seguidas de mesma letra, nas colunas, não diferem entre si, pelo teste de Tukey $(P \leq 0,05)$. 
Tabela 12. Médias ( \pm EP) de duração das fases de ovo, ninfa e ovo-adulto de Bemisia tabaci biótipo B em tomateiro após aplicação de extratos aquosos de meliáceas sobre ovos e ninfas. Temp.: $25,5 \pm 4,6^{\circ} \mathrm{C}$; UR: $65,3 \pm 13,7 \%$; fotoperíodo natural.

\begin{tabular}{lccc}
\hline \multirow{2}{*}{ Extratos } & \multicolumn{3}{c}{ Duração (dias) } \\
\cline { 2 - 4 } & Ovo & Ninfa & Ovo-adulto \\
\hline T. pallida (ramos) & $6,70 \pm 0,10$ & $12,89 \pm 0,06$ & $19,59 \pm 0,10$ \\
M. azedarach (frutos verdes) & $6,64 \pm 0,06$ & $12,95 \pm 0,12$ & $19,59 \pm 0,06$ \\
A. indica (sementes) & $6,57 \pm 0,08$ & $12,93 \pm 0,17$ & $19,50 \pm 0,19$ \\
Testemunha & $6,68 \pm 0,07$ & $12,98 \pm 0,18$ & $19,66 \pm 0,16$ \\
\hline
\end{tabular}

${ }^{1}$ Médias, nas colunas, não diferem entre si, pelo teste de Tukey $(P \leq 0,05)$. 


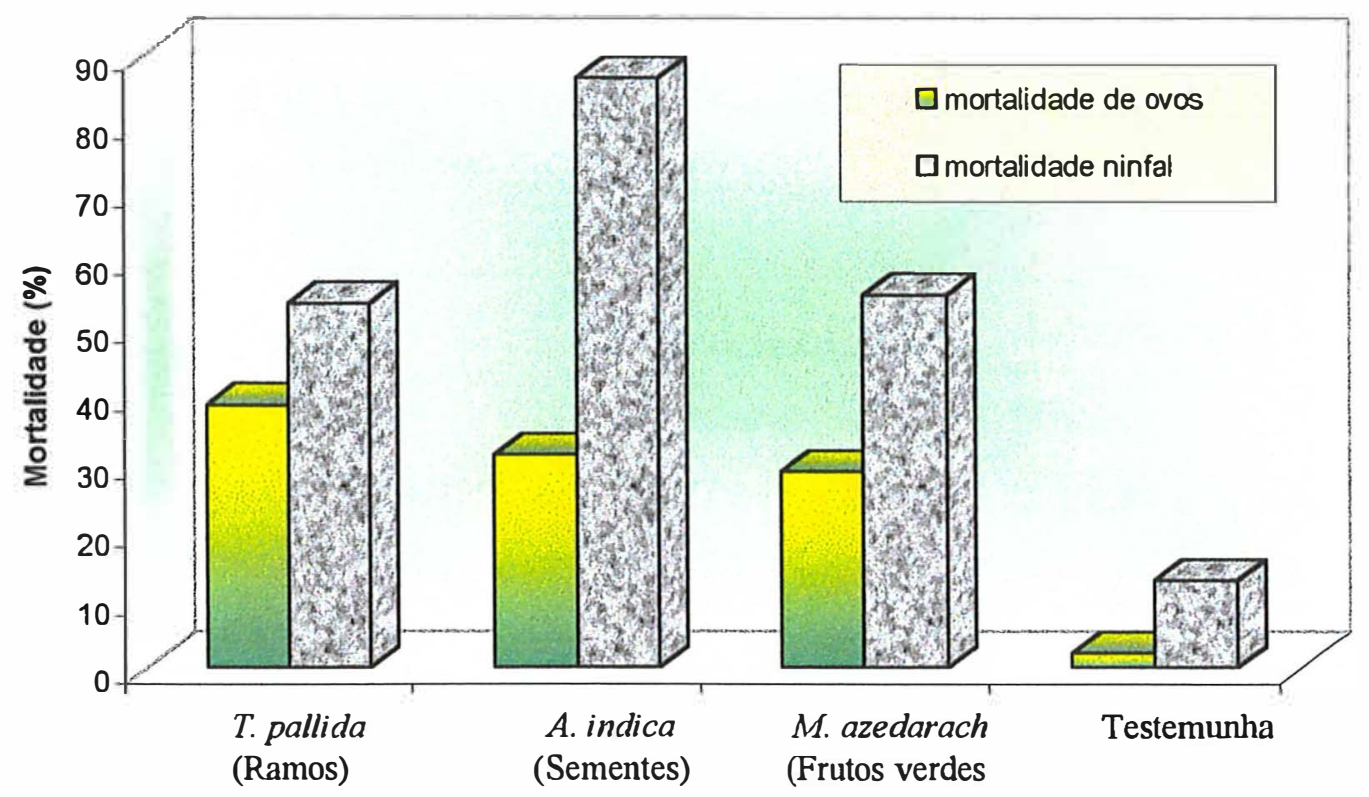

Figura 6. Médias de mortalidade das fases de ovo, ninfa e ovo-adulto de Bemisia tabaci biótipo $B$, em tomateiro, após aplicação de extratos aquosos de três meliáceas sobre ovos e ninfas. Temp.: $25,5 \pm 4,6^{\circ} \mathrm{C}$; UR: $65,3 \pm 13,7 \%$; fotoperíodo natural. 
Tabela 13. Médias ( \pm EP) de mortalidade ninfal, longevidade dos adultos de Bemisia tabaci biótipo $\mathrm{B}$, em tomateiro, após aplicação de extratos aquosos de meliáceas sobre as ninfas. Temp.: $25,0 \pm 2,0^{\circ} \mathrm{C}$; UR: $70,0 \pm 10,0 \%$; fotofase: $12 \mathrm{~h}$.

\begin{tabular}{lcccc}
\hline \multirow{2}{*}{ Extratos } & \multirow{2}{*}{\begin{tabular}{c} 
Mortalidade \\
\cline { 3 - 4 }
\end{tabular}} & \multicolumn{2}{c}{ Longevidade (dias) $^{\mathbf{1}}$} \\
\cline { 3 - 5 } & ninfal (\%) & Macho & Fêmea \\
\hline Melia azedarach (frutos verdes) & $68,66 \pm 1,79$ b & $7,71 \pm 1,67$ a & $9,27 \pm 1,03$ b \\
Trichilia pallida (ramos) & $64,91 \pm 4,46$ b & $7,30 \pm 1,23$ a & $7,67 \pm 0,56$ b \\
Testemunha & $19,19 \pm 5,79$ c & $8,08 \pm 0,69$ a & $9,99 \pm 1,36$ ab
\end{tabular}

${ }^{1}$ Médias seguidas de mesma letra, nas colunas, não diferem entre si, pelo teste de Tukey $(P \leq 0,05)$.

Tabela 14. Médias ( \pm EP) de fecundidade de Bemisia tabaci biótipo $B$, em tomateiro, após aplicação de extratos aquosos de meliáceas sobre as ninfas. Temp.: $25,0 \pm 2,0^{\circ} \mathrm{C}$; UR: $70,0 \pm 10,0 \%$; fotofase: $12 \mathrm{~h}$.

\begin{tabular}{|c|c|c|}
\hline \multirow{2}{*}{ Extratos } & \multicolumn{2}{|c|}{ Fecundidade $^{1}$} \\
\hline & Ovos/fêmea & Ovos/fêmea/dia \\
\hline Azadirachta indica (sementes) & $23,77 \pm 3,12 a$ & $2,04 \pm 0,32 a$ \\
\hline Melia azedarach (frutos verdes) & $13,88 \pm 1,79 b$ & $1,50 \pm 0,49 a$ \\
\hline Trichilia pallida (ramos) & $15,38 \pm 4,46 a b$ & $1,99 \pm 4,46 a$ \\
\hline Testemunha & $18,70 \pm 5,79 a b$ & $1,86 \pm 0,49 a$ \\
\hline
\end{tabular}

${ }^{1}$ Médias seguidas de mesma letra, nas colunas, não diferem entre si, pelo teste de Tukey $(P \leq 0,05)$. 


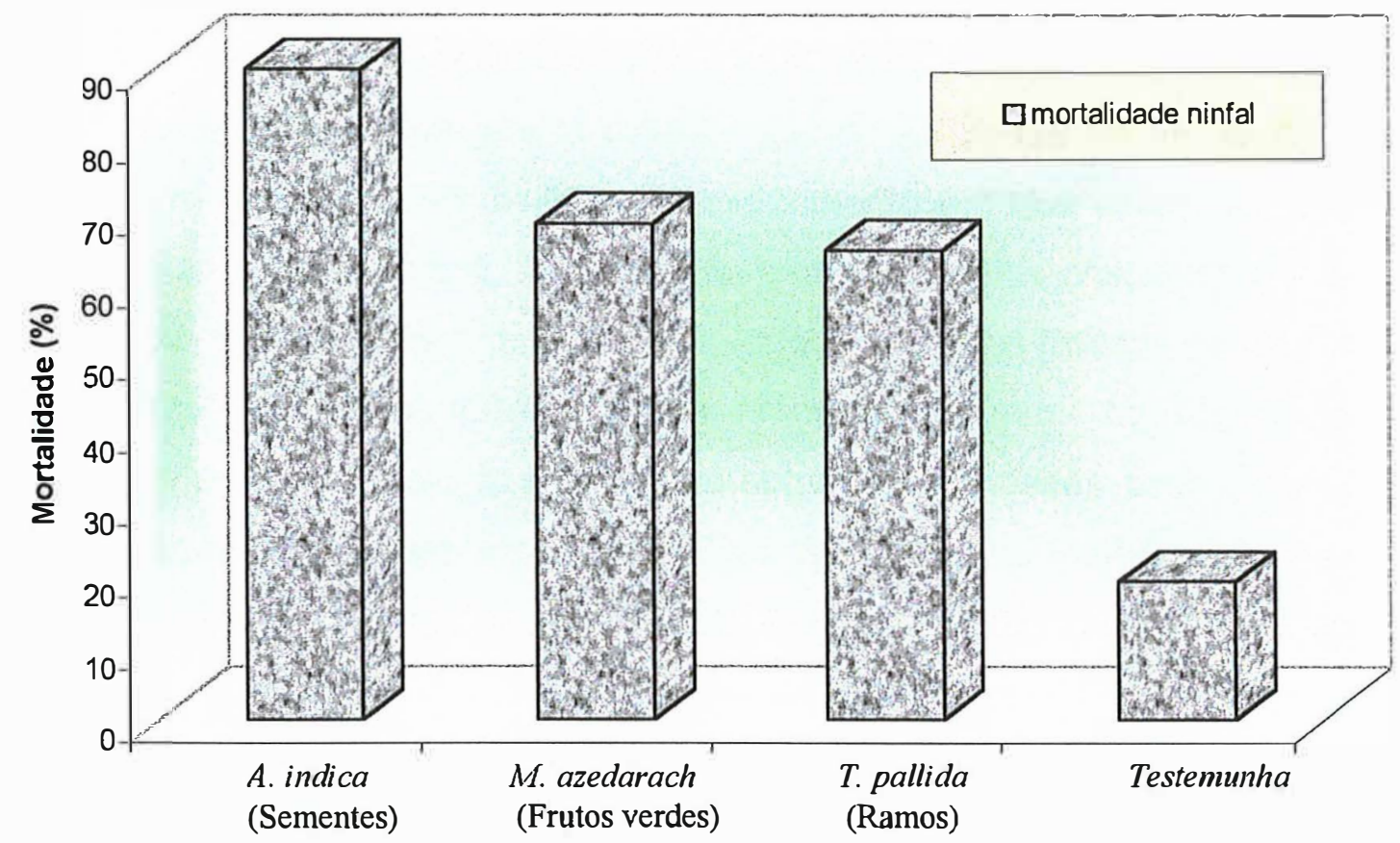

Figura 7. Médias de mortalidade ninfal de Bemisia tabaci biótipo $B$, em tomateiro, após aplicação de extratos aquosos de meliáceas sobre as ninfas. Temp.: $25,0 \pm 2,0^{\circ} \mathrm{C}$; UR: $70,0 \pm 10,0 \%$; fotoperíodo natural. 


\subsection{Considerações finais}

As três espécies de meliáceas testadas (T. pallida, M. azedarach e A. indica) apresentaram efeito ovicida quando utilizadas na forma de extrato aquoso na concentração de 3\%. No experimento em que estas três espécies foram comparadas entre si, T. pallida foi a mais eficiente, chegando a superar o extrato de sementes de nim. Foi observado que alguns insetos completaram o desenvolvimento embrionário, mas morreram sem conseguir romper completamente o córion do ovo, o que sugere que, nesses casos, os extratos não teriam afetado a embriogênese. Este tipo de efeito também foi observado por Liu e Stansly (1995a) e por Prabhaker et al. (1999), ao aplicarem um óleo comercial e o inseticida amitraz, respectivamente, sobre ovos de $B$. tabaci biótipo $\mathrm{B}$. Estes últimos autores mencionaram que a morte possivelmente tenha ocorrido devido aos resíduos dos extratos depositados sobre o córion. Esta hipótese, entretanto, provavelmente não explica o que ocorreu na presente pesquisa, já que, nesse caso, as ninfas recém-formadas mortas não chegaram a sair do ovo e, desse modo, não teriam tido contato com os possíveis resíduos dos extratos.

Informações referentes ao efeito ovicida de extratos botânicos aplicados diretamente sobre ovos de Bemisia spp. são escassas na literatura, restringindo-se aos trabalhos de Coudriet et al. (1985) e Prabhaker et al. (1989, 1999) que registraram esse efeito sobre $B$. tabaci com o uso de nim em extrato aquoso e em formulação comercial, respectivamente.

Os extratos aplicados sobre os ovos não afetaram a sobrevivência ninfal. Considerando-se que a fase de ovo da mosca branca é mais difícil de ser controlada que a fase de ninfa (Coudriet et al., 1985 e Prabhaker et al., 1989, 1999), os dados obtidos sugerem que quando os insetos atingiram a fase ninfal, os compostos ativos presentes nas referidas meliáceas já se encontravam em nível residual insuficiente para afetar o inseto nessa fase.

No que se refere ao nim, esses dados, em princípio, diferem dos 
obtidos por Coudriet et al. (1985a), que, aplicando o extrato aquoso de nim (2\%) sobre ovos de B. tabaci, constataram efeito também sobre a fase ninfal, matando $90 \%$ delas ainda no primeiro ínstar. Deve-se considerar, entretanto, que no trabalho desses autores, o extrato foi misturado com um surfactante, 0 qual, segundo Sundaram et al. ${ }^{1}$, citado por Jarvis et al. (1998), retarda consideravelmente a decomposição da azadiractina, o que pode ter auxiliado a persistência do extrato de modo a afetar as ninfas (principalmente as de primeiro ínstar). Quando os produtos à base de nim foram aplicados sobre as ninfas, a mortalidade máxima ocorreu de 2 a 5 dias após 0 tratamento ou durante a ecdise, o que foi atribuído pelos autores à ação do extrato no sistema neuro-endócrino de ecdiesteróides ou como anti-ecdiesteróide. Efeito de extratos acetônicos de folhas e sementes de nim na ecdise do percevejo Dysdercus cingulatus também já tinha sido referido por Abraham \& Ambika (1979).

Quando os extratos foram aplicados diretamente sobre as ninfas, na concentração de $3 \%$, foi constatada mortalidade significativa nessa fase para a maioria das estruturas vegetais testadas (frutos verdes, frutos maduros $\mathrm{e}$ folhas de $M$. azedarach, ramos de T. pallida e sementes de $A$. indica), não sendo observado efeito apenas dos extratos de ramos de $M$. azedarach e de córtex e folhas de $T$. pallida.

A mortalidade ninfal causada pelo uso de sementes de $A$. indica confirma resultados divulgados na literatura, tanto com a utilização de extratos aquosos (Coudriet et al., 1985), como com a utilização de formulações comerciais à base de sementes em diversas concentrações (Leskovar \& Boales, 1996; Liu \& Stansly, 1995b; Natarajan \& Sundaramurthy, 1990; Prabhaker et al., 1989, 1999 e Puri et al., 1994). Nos experimentos de Prabhaker et al. (1999), a aplicação de uma formulação comercial de sementes de nim no solo, nas sementes e nas folhas da planta hospedeira (algodoeiro) provocou mortalidade

\footnotetext{
${ }^{1}$ SUNDARAM, K.M.S.; SLOANE, L.; CURRY, J. Kinetics of azadirachtin hydrolysis in model aquatic systems by high performance liquid chromatography. Journal of Liquid Chromatography, v.18, p.363-376, 1995.
} 
de ovos e ninfas em todos os tratamentos, indicando que esse produto apresenta ação sistêmica; o efeito sobre as ninfas na aplicação foliar, pode ser atribuído, por outro lado, ao efeito residual, uma vez que o extrato foi aplicado antes da oviposição. Segundo Osman \& Port (1990), a liberação gradual dos compostos químicos do nim incorporado no solo e sua gradual absorção e translocação pela planta aumenta a sua persistência, já que, no solo, o composto fica protegido da luz solar, que degrada o produto. Não existem informações sobre a ação sistêmica de extratos de outras meliáceas e, em vista da boa atividade inseticida de $M$. azedarach e $T$. pallida contra mosca branca, seria interessante a avaliação desse tipo de ação nas referidas plantas.

Não há dados na literatura a respeito da ação tóxica de $M$. azedarach e $T$. pallida especificamente sobre ninfas de $B$. tabaci, embora em relação a M. azedarach, Sabillón \& Bustamante (1995) tenha relatado que extratos aquosos (a 5\%) dos frutos tenham provocado redução da população dessa praga, em condições de campo, o que se supõe ter sido provocada principalmente pela mortalidade do inseto nessa fase.

Comparando-se os efeitos letais sobre ovos e sobre ninfas quando os extratos foram aplicados diretamente sobre as respectivas fases, verifica-se que em nenhum dos tratamentos o efeito ovicida foi superior ao efeito sobre as ninfas. Ao contrário, embora esses efeitos não tenham sido comparados estatisticamente, constata-se que aparentemente os extratos de frutos verdes e de frutos maduros de $M$. azedarach, de ramos de $T$. pallida (em dois dos experimentos) e de sementes de $A$. indica apresentaram maior atividade inseticida sobre ninfas que sobre ovos da mosca branca, o que sugere que essa última fase é mais resistente à ação dos extratos dessas duas estruturas vegetais. $\mathrm{O}$ maior efeito de produtos à base de $A$. indica sobre ninfas que sobre ovos de Bemisia spp. também foi verificado por Coudriet et al. (1985) e Prabhaker et al. $(1989,1999)$.

Não foi constatado efeito prejudicial dos extratos, mesmo na concentração de $3 \%$, sobre a duração do período de incubação e da fase ninfal 
da mosca branca. No caso do período de incubação, ao menos em alguns casos, isso teria ocorrido pelo fato dos extratos não terem afetado a embriogênese, conforme mencionado anteriormente.

As informações sobre o prolongamento da fase ninfal de $B$. tabaci por extratos de meliáceas estão restritas aos dados de Coudriet et al. (1985) que observaram estes efeito com extrato de sementes de nim a $2 \%$. Em relação a outras pragas e envolvendo as meliáceas testadas no presente trabalho, pesquisas evidenciando o alongamento do período de desenvolvimento já foram citadas na literatura. Em relação a $M$. azedarach, esse alongamento foi referido para S. frugiperda (Chen et al., 1996; McMillian et al., 1969; Mikolajczak et al., 1989; Rodríguez Hernández \& Vendramim, 1997, 1998 e Vendramim \& Scampini, 1997) e Heliothis armigera (Hübner) (Anwar et al., 1992) enquanto para T. pallida há citações em relação a $S$. frugiperda (Rodríguez Hernández, 1995; Torrecillas, 1997 e Roel, 1998) e Tuta absoluta (Thomazini, 1999). O alongamento da fase imatura causada por produtos derivados de $A$. indica tem sido verificado em relação a diversas pragas, incluindo algumas de hábito sugador (Dimetry \& El-Hawary, 1995 e Dom et al., 1986)

Além do efeito ovicida e da mortalidade ninfal de $B$. tabaci, outros efeitos de produtos à base de $M$. azedarach e principalmente de $A$. indica sobre essa praga têm sido citados. Em relação a $M$. azedarach, tem sido verificada redução da oviposição e mortalidade de adultos (Nardo e al., 1997), enquanto em relação a $A$. indica, tem sido observada redução da oviposição (Coudriet et al., 1985; Cubillo et al., 1994; Gomez et al., 1997a e Prabhaker et al., 1999); alongamento da fase ninfal (Coudriet et al., 1985); anormalidades morfológicas em adultos (Natarajan \& Sundaramurthy, 1990); mortalidade de adultos (Prabhaker et al., 1989). Redução na população de adultos provocada por aplicações de produtos derivados de nim (sem que os autores tenham mencionado o tipo de efeito causado) também tem sido mencionada (Leskovar \& Boales, 1996 e Sabillón \& Bustamante, 1995).

Nos experimentos visando à comparação das estruturas vegetais, 
foi constatado efeito diferenciado tanto com $M$. azedarach como com $T$. pallida. Em relação a $M$. azedarach, a maior eficiência sobre $B$. tabaci foi registrada com o uso de frutos verdes, vindo a seguir as folhas, os frutos maduros e os ramos. No que se refere a $T$. pallida, o extrato de ramos foi o mais efetivo, seguindo-se as folhas, enquanto o córtex não apresentou bioatividade.

A variação no efeito de uma planta inseticida em função da estrutura vegetal utilizada para o preparo do extrato se deve ao fato dos compostos fitoinseticidas não estarem distribuídos uniformemente por toda a planta. Em A. indica, por exemplo, segundo Balandrin et al. (1988), de um total de 25 componentes voláteis até então identificados, cerca de $75 \%$ estavam presentes nas sementes, enquanto os demais estavam em outras partes vegetais.

Em relação às espécies vegetais estudadas no presente trabalho, diversas pesquisas têm demonstrado esse efeito variável. Assim, Rodríguez Hernández (1995), comparando os extratos aquosos de folhas, caules (ramos) e frutos de $M$. azedarach em relação às lagartas de quarto ínstar de $S$. frugiperda, verificou que o extrato de caule foi deterrente, enquanto os extratos de folhas e de frutos foram fagoestimulantes, resultado que permite inferir que há bastante variação nos componentes químicos presentes nas estruturas vegetais dessa espécie vegetal. Este autor, entretanto, avaliando toda a fase imatura do inseto, constatou que as três estruturas vegetais (incorporadas em dieta artificial) afetaram severamente o desenvolvimento larval, verificando maior bioatividade dos extratos de ramos e folhas, os quais, dependendo da concentração, provocaram $100 \%$ de mortalidade larval.

Já no que se refere a $T$. pallida, a comparação do efeito dos extratos de folhas e de caules (ramos) de $T$. pallida no desenvolvimento de $S$. frugiperda, indicou a maior eficiência dos ramos em relação às folhas, tanto na forma de extratos aquosos (Rodríguez Hernández, 1995 e Torrecillas, 1997) como de extratos orgânicos (Roel, 1998), verificando-se também, em todos esses trabalhos, mortalidade toial (tanto com folhas como com ramos) 
dependendo da concentração utilizada. Thomazini (1999), comparando extratos de folhas e de ramos em relação à traça do tomateiro, $T$. absoluta, constatou maior eficiência com folhas. Rodríguez Hernández (1995), por outro lado, avaliando os extratos aquosos de folhas e caules (ramos) dessa meliácea em relação às lagartas de quarto ínstar de $S$. frugiperda, constatou que enquanto o extrato de ramos foi deterrente alimentar, o extrato de folhas apresentou efeito fagoestimulante, o que permite concluir que, analogamente ao foi verificado com $M$. azedarach, também com $T$. pallida, há bastante variação nos componentes químicos presentes nas suas estruturas vegetais.

A variação da bioatividade de meliáceas contra diversas outras pragas em função da estrutura vegetal utilizada para o preparo dos extratos tem sido constatada por diversos autores, envolvendo tanto extratos aquosos (Rodríguez Hernández, 1995; Torrecillas, 1996; Xie et al., 1994) como aqueles obtidos com outros solventes (Ascher et al., 1984; McMillian et al., 1969; Mikolajczak et al., 1989; Mikolajczak \& Reed, 1987; Singh et al., 1988).

A descoberta da atividade inseticida do extrato de $T$. pallida e a confirmação dessa atividade nos extratos de $M$. azedarach sobre $B$. tabaci devem propiciar novos estudos visando determinar as substâncias químicas responsáveis por essa atividade, bem como avaliar as concentrações efetivas em condições de campo, a persistência, os mecanismos de ação e os demais aspectos necessários para viabilizar o uso comercial dos referidos extratos para controle dessa praga. 


\section{CONCLUSÕES}

Com base nos resultados obtidos com o uso de extratos aquosos de Melia azedarach, Trichilia pallida e Azadirachta indica no controle da mosca branca Bemisia tabaci (Gennadius, 1889) biótipo B, podem ser estabelecidas as seguintes conclusões:

- A concentração de $3 \%$ é adequada para avaliação do efeito de extratos aquosos de $T$. pallida e $M$. azedarach sobre a mosca branca.

- Extratos de frutos verdes, de folhas e de frutos maduros de $M$. azedarach provocam mortalidade da fase imatura do inseto, sendo os dois primeiros mais eficientes.

- Extratos de ramos e de folhas de T. pallida afetam a sobrevivência da fase imatura do inseto, enquanto o extrato de córtex não apresenta ação inseticida.

- Extratos de ramos de $T$. pallida, de frutos verdes de $M$. azedarach e de sementes de $A$. indica, na concentração de $3 \%$, apresentam atividade inseticida sobre ovos e ninfas do inseto, sendo o primeiro deles o mais eficiente em relação aos ovos e o último o mais eficiente em relação às ninfas.

- Extratos aplicados sobre os ovos do inseto não exercem efeito inseticida sobre as ninfas.

- A duração da fase imatura do inseto não é afetada pela aplicação dos extratos sobre ovos e ninfas.

- A fecundidade e longevidade dos adultos não são afetadas pela aplicação dos extratos sobre ninfas. 


\section{REFERÊNCIAS BIBLIOGRÁFICAS}

ABRAHAM, C.C.; AMBIKA, B. Effect of leaf and kernel extracts of neem on moulting and vitellogenesis in Dysdercus cingulatus Fabr. (Heteroptera: Pyrrhocoridae). Current Science, v.48, n.48, p.554-555, 1979.

ALDHOUS, P. Neem chemical: the pieces falll in place. Science, v.258, p.893, 1992.

ANWAR, T.; JABBAR, Z.; KHALIQUE, F.; THAIR, S.; SHAKEEL, M.A. Plants with insecticidal activities against four major insect pests in Pakistan. Tropical Pest Management, v.38, n.4, p.431-437, 1992.

ARNASAN, J.T.; PHILOGENE, B.J.R.; MORAND, P. Inseticides of plant origin. Washington: American Chemical Society, 1989. (ACS. Symposium Series, 387).

ASCHER, K.R.S. Nonconventional insecticidal effects of pesticides available form the neem tree, Azadirachta indica. Archives of Insect Biochemistry and Physiology, v.22, n.3/4, p.433-449, 1993.

ASCHER, K.R.S.; ELIYAHU, M.; NEMNY, N.E.; MEISNER, J. Neem seed kernel extract as an inhibitor of growth and fecundity in Spodoptera littoralis. In: INTERNATIONAL NEEM CONFERENCE, 2., Ruischholzhauzen, 1983. Natural pesticides from the neem tree (Azadirachta indica A. Juss) and other tropical plants. Eschborn:GTZ Press, 1984, p. 331-344. 
ASIATICO, J.M.; ZOEBISCH, T.G. Control de mosca blanca Bemisia tabaci (Gennadius) en tomate com insecticidas de origen biologico y quimico. Manejo Integrado de Plagas, v.24/25, p.1-7, 1992.

AVILÉS, R.; ESTRADA, J.; MORALES, M.; CHIANG, M.G.; GUIBERT, G.; STOMAYOR, E. Control of Cylas formicarius elegantulus F. (sweetpotato weevil) with neem and chinaberry seeds products. In: TALLER INTERNATIONAL Y TERCERO NACIONAL, BIOPLG 95, PLAGUICIDAS BIOLÓGICOS DE ORIGEN BOTÁNICO, 1. Instituto de Investigaciones Fundamentales en Agricultura Tropical "Alejandro de Humboldt". Centro de Informatión y Documentatión Agropecuário, 1995, p.77.

BALANDRIN, M.F.; MARK-LEE, S.; KLOCKE, J.A. Biologically active volatile organosulfur compounds from seeds of the neem tree, Azadirachta indica (Meliaceae). Journal of Agricultural and Food Chemistry, v.36, n.5, p.1048-1054, 1988.

BEDFORD, I.D.; BRIDDON, R.W.; BROWN, J.K.; ROSELL, R.C.; MARKHAN, P.G. Geminivirus transmission and biological characterization of Bemisa tabaci (Gennadius) biotypes from different geographic regions. Annals of Applied Biology, v.125, p.311-325, 1994.

BELLOWS JUNIOR, T.S.; PERRING, T.M.; GILL, R.J.; HEADRICK, D.H. Description of a species of Bemisia (Homoptera: Aleyrodidae). Annals of Entomology of the Society of America, v.87, n.2, p.195-206, 1994.

BENTZ, J.; NEAL JUNIOR, J.W. Effect of a natural insecticide from Nicotiana gossei on the whitefly parasitoid Encarsia formosa (Hymenoptera: Aphelinidae). Journal of Economic Entomology, v.88, n.6, p. 1611-1615, 1995. 
BERLINGER, M.J. Host plant resistance to Bemisia tabaci. Agriculture, Ecosystems and Environment, v.17, p.69-82, 1986.

BETHKE, J.A.; PAINE, T.D.; NUESSLY, G.S.; Comparative biology, morphometrics, and development of two populations of Bemisia tabaci (Homoptera: Aleyrodidae) on cotton and poinsettia. Annals of the Entomological Society of America, v.84, n.4, p.407-411, 1991.

BINK-MOENEM, R.M.; MOUND, L.A. Whiteflies: Diversity, byosystematics and evolutionary patterns. In: Gerling, D. (Ed.) Whiteflies: their bionomics, pests status and management Winborne: Intercept, 1990. cap.1, p.1-12.

BLUA, M.J.; YOSHIDA, H.A.; TOSCANO, N.C. Oviposition preference of two Bemisia species (Homoptera: Aleyrodidae). Environmental Entomology, v.24, n.1, p. 88-93, 1995.

BROWN, J.K. Current status of Bemisia tabaci as a plant pest and virus vector in agroecosystems worldwide. FAO Plant Protection Bulletin, v.42, n.1/2, p.3-33, 1994.

BROWN, J.K.; FROHLICH, D.R.; ROSELL, R.C. The sweetpotato or silverleaf whiteflies: Biotypes of Bemisia tabaci or a species complex? Annual Review of Entomology, v.40, p.511-534, 1995.

BURBAN, C.; FISHPOOL, L.D.C.; FAUQUET, C.; FARGUETTE, D.; THOUVENEL, J.C. Host-associated biotypes within west African populations of the whitefly Bemisia tabaci (Genn.) (Hom., Aleyrodidae). Journal of Applied Entomology, v.113, p.416-423, 1992. 
BUTLER JUNIOR., G.D.; WILSON, F.D. Activity of adult whiteflies (Homoptera: Aleyrodidae) withing plantings of different cotton strains and cultivars as determined by sticky-trap catches. Journal of Economic Entomology, v.79, p.1137-1140, 1984.

BUTLER JUNIOR., G.D.; RIMON JUNIOR., D..; HENNEBERRY, T.J. Bemisia tabaci (Homoptera: Aleyrodidae): Populations on different cotton varieties and cotton stickiness in Israel. Crop Protection, v.7, p.43-47, 1988.

BYRNE, D.N.; BELLOWS JUNIOR, T.S. Whitefly biology. Annual Review of Entomology, v.36, p.431-457, 1991.

BYRNE, D.N.; MILLER, W.B. Carbohydrate and amino acid composition of phloem sap and honeydew produced by Bemisia tabaci. Journal of Insect Physiology, v.36, n.6, p.433-439, 1990.

CABALLERO, R. Clave de campo para imaduros de moscas blancas de Centroamérica (Homoptera: Aleyrodidae). Zamorano: Escuela Agricola Panamericana, 1994. 4 p.

CASTLE, S.; HENNEBERRY, T.; TOSCANO, N.; PRABHAKER, N.; BIRDSALL, S.; WEDDLE, D. Silverleaf whiteflies show no increase in insecticide resistance. California Agriculture, v.50, n.1, p.18-23, 1996.

CENTRO AGRONÓMICO TROPICAL DE INVESTIGACIONES Y ENSENÃNZA. Neem (Azadirachta indica) como plaguicida natural: bibliografia. Turrialba, 1991. 38 p. (CATIE. Documentación y Información, 7). 
CHEN, C.C.; CHANG, S.J.; CHENG, L.L.; HOU, R.F. Effects of chinaberry fruit extract on feeding, growth and fecundity of the diamondback moth, Plutella xylostella L. (Lep., Yponomeutidae). Journal of Applied Entomology, v.120, p.341-345, 1996.

COHEN, S.; DUFFUS, J.E.; LIU, H.Y. A new Bemisia tabaci biotype in the southwestern United States and its role in silverleaf of squash and transmission of lettuce infectious yellows virus. Phytopatology, v.82, n.1, p.86-90, 1992.

COSTA, A.S.; RUSSEL, L.M. Failure of Bemisia tabaci to breed on cassava plants in Brazil (Homoptera: Aleyrodidae). Ciência \& Cultura, v.27, p.388$390,1975$.

COSTA, H.S.; BROWN, J.K. Variability in biological characteristics, isozyme patterns and virus transmission among populations of Bemisia tabaci in Arizona. Phytopathology, v.80, p.888, 1990.

COSTA, H.S.; BROWN, J.K. Variation in biological characteristcs and sterase patterns among populations of Bemisia tabaci Genn. and the association of one population with silverleaf symptom induction. Entomologia Experimentalis et Applicata, v.61, p.211-219, 1991.

COSTA, H.S.; BROWN, J.K.; BYRNE, D.N. Life history traits of the whitefly, Bemisia tabaci (Homoptera:Aleyrodidae) on six virus-infected or healthy plant species. Environmental Entomology, v.20, n.4, p.1102-1107, 1991.

COSTA, H.S.; ULLMAN, D.E.; JOHNSON, M.W.; TABASHNIK, B.E. Squash silverleaf symptoms induced by immature, but not adult, Bemisa tabaci. Phytopathology, v.83, n.7, p.763-766, 1993. 
COUDRIET, D.L.; PRABHAKER, N.; MEYERDIRK, D.E. Sweetpotato whitefly (Homoptera: Aleyrodidae): Effects of neem-seed extract on oviposition and immature stages. Environmental Entomology, v.14, n.6, p.776-779, 1985a.

COUDRIET, D.L.; PRABHAKER, N.; KISHABA, A.N.; MEYERDIRK, D.E. Variation in developmental rate on different hosts and overwintering of the sweetpotato whitefly, Bemisia tabaci (Homoptera: Aleyrodidae). Environmental Entomology, v.14, p.516-559, 1985b.

CUBILLO, D.; SANABRIA, G.; HILJE, L. Mortalidad de adultos de Bemisia tabaci con extractos de hombre grande (Quassia amara). Manejo Integrado de Plagas, v.45, p.25-28, 1997.

CUBILLO, D.; QUIJIJE, R.; LARRIVA, W.; CHACÓN, A.; HILJE, L. Evaluación de la repelencia de varias substancias sobre la mosca blanca Bemisia tabaci (Homoptera: Aleyrodidae). Manejo Integrado de Plagas, v.33, p.2628, 1994.

DE BARRO, P.J. Bemisia tabaci biotype B: a review of its biology, distribution and control. Camberra:CSIRO, 1995. 58 p.

DIMETRY, N.Z.; EL-HAWARY, F.M.A. Neem AZAL-F as an inhibitor of growth and reproduction in the cowpea aphid Aphis craccivora Koch. Journal of Applied Entomology, v.119, p.67-71, 1995.

DITTRICH, V.; ERNST, G.H.; RUESCH, O.; UK, S. Resistance mechanisms in sweetpotato whitefly (Homoptera: Aleyrodidae) populations from Sudan, Turkey, Guatemala and Nicaragua. Journal of Economic Entomology, v.83, n.5, p.1665-1670, 1990. 
DORN, A.; RADEMACHER, J.M.; SEHN, E. Effects of azadirachtin on the moulting cycle, endocrine system, and ovaries in last-instar larvae of the milkweed bug, Oncopeltus fasciatus. Journal of Insect Physiology, v.32, n.3, p.231-238, 1986.

EICHELKRAUT, K.; CARDONA, C. Biología, cria massal y aspectos ecológicos de la mosca blanca Bemisia tabaci (Gennadius) (Homoptera; Aleyrodidae), com plaga del frijol comum. Turrialba, v.39, n.1, p.55-62, 1989.

ENKEGAARD, A. The poinsettia strain of the cotton whitefly, Bemisia tabaci (Homoptera:Aleyrodidae), biological and demographic parameters on poinsettia (Euphorbia pulcherrima) in relation to temperature. Bulletin of the Entomological Research, v.83, p.535-546, 1993.

FAUQUET, C.; FARGETTE, D. African cassava mosaic virus: etiology, epidemiology, and control. Plant Disease, v.74, p.404-411, 1990.

FELDHEGE, M.; SCHNUTTERER, $H$. Investigations on side-effects of Margosan-O on Encarsia formosa Gah. (Hym., Aphelinidae), parasitoid of the greenhouse whitefly, Trialeurodes vaporariorum Westw. (Hom., Aleyrodidae). Journal of Applied Entomology, v.115, p.37-42, 1993.

FLINT, H.M.; PARKS, N.J. Effect of azadirachtin from the neem tree on immature sweetpotato whitefly, Bemisia tabaci (Homoptera: Aleyrodidae) and other selected pest species on cotton. Journal of Agricultural Entomology, v.6, p.211-215, 1989.

FRANÇA F.H.; VILLAS BOAS, G.L.; BRANCO, M.C. Ocorrência de Bemisia argentifolii Bellows \& Perring (Homoptera: Aleyrodidae) no Distrito Federal. Anais da Sociedade Entomológica do Brasil, v.25, n.2, p. 369-372, 1996. 
GERLING, D.; HOROWITZ, A.R.; BAUMGAERTNER, J. Autecology of Bemisia tabaci. Agriculture, Ecosystems \& Environment, v.17, p.5-19, 1986.

GILL, J.S.; LEWIS, C.T. Systemic action of an insect feeding deterrent. Nature, v.232, p.402-403, 1971.

GÓMEZ, P.; CUBILLO, D.; MORA, G.A.; HILJE, L. Evaluación de possibles repelentes de Bemisia tabaci: I. Productos comerciales. Manejo Integrado de Plagas, v.46, p.9-16, 1997a.

GÓMEZ, P.; CUBILLO, D.; MORA, G.A.; HILJE, L. Evaluación de possibles repelentes de Bemisia tabaci: II. Extractos vegetables. Manejo Integrado de Plagas, v.46, p.17-25, 1997b.

GOVINDACHARI, T.R. Chemical and biological investigation on Azadirachta indica (the neem tree). Current Science, v.63 n.3, p.117-122, 1992.

GRAINGE, M.; AHMED. S. Handbook of plants with pest control properties. New York:John Wiley, 1988. 470 p.

HOFFMAN C.J.; BYRNE, D.N. Effects of temperature and photoperiod upon adult eclosion of the sweetpotato whitefly Bemisia tabaci. Entomologia Experimentalis et Applicata, v.42, p.139-143, 1986.

HOROWITZ, A.R.; GERLING, D. Seasonal variation of sex ratio in Bemisia tabaci on cotton in Israel. Environmental Entomology, v.21, n.3, p.556559, 1992. 
HOROWITZ, A.R.; TOSCANO, N.C.; YOUNGMAN, R.R.; GEORGHION, G.P. Synergism of insecticides with DEF in sweetpotato whitefly (Homoptera: Aleyrodidae). Journal of Economic Entomology, v.81, n.1, p.110-114, 1988.

ISMAN, M. B.; KOUL, O.; LUCZYNSKI, A.; KAMINSKI, J. Insecticidal and antifeeding bioactivities of neem oils and their relationship to azadirachtin content. Journal of Agricultural Food Chemistry, v.38, p.1406-1411, 1990.

JACOBSON, M.; REED, D.K.; CRYSTAL, M.M.; MORENO, D.S.; SODERSTROM, E.L. Chemistry and biological activity of insect feeding deterrents form certain weed and crop plants. Entomologia Experimentalis et Applicata, v.24, n.3, p.448-457, 1978.

JACOBSON, M., (Ed.). The neem tree. Boca Ratón:CRC Press, 1988. 178 p. (Focus on Phytochemical Pesticides, 1).

JARVIS, A.P.; JOHNSON, S.; MORGAN, E.D. Stability of natural insecticide azadirachtin in aqueous and organic solvents. Pesticide Science, v.53, p.217-222, 1998.

JOTWANI, M.C.; SRIVASTAVA, K.P. Neem, insecticide of the future-II; Protection against field pest. Pesticides, v.15, n.11, p.40-47, 1981.

KOUL, O. Neem allelochemicals and insect control. In: RIZVI, SJ.H.; RIZVI, V. (Ed.) Allelopathy: basic and applied aspects. London: Chapman \& Hall, 1992. cap.23, p.389-412. 
KOUL, O.; ISMAN, M.B.; KETKAR, C.M. Properties and uses of neem, Azadirachta indica. Canadian Journal of Botany, v.68, n.1, p.1-11, 1990.

LAGUNES T., A.; RODRÍGUEZ H., C. Los extractos acuosos vegetales com actividad insecticida; el combate de la conchuela del frijol. Montecillo: USAID; CONACYT; Soc. Mex. Entomol.; Collegio de Postgraduados, 1992. 57p. (Temas Selectos de Manejo de Insectidas Agrícolas, 3).

LAGUNES T., A.; ARENAS L.C.; RODRÍGUEZ H., C Extractos acuosos y polvos vegetales con propiedades insecticidas. Chapingo: Colégio de Postgraduados, Centro de Entomología y Acarologia, 1984. 203 p.

LESKOVAR, D.I.; BOALES, A.K. Azadirachtin. Potential use for controlling lepidopterous insects and increasing marketability of cabbage. Hortscience, v.31, n.3, p.405-409, 1996.

LIU, T.X.; STANSLY, P.A. Deposition and bioassay of inseticides applied by leaf dip and spray tower against Bemisia argentifolii (Homoptera: Aleyrodidae). Pesticide Science, v.44, p.317-322, 1995a.

LIU, T.X.; STANSLY, P.A. Toxicity of biorational insecticides to Bemisia argentifolii (Homoptera: Aleyrodidae) on tomato leaves. Journal of Economic Entomology, v.88, n.3, p.564-568, 1995b.

LIU, T.X.; STANLY, P.A. Toxicological effects of selected insecticides on Nephaspis oculatus (Col., Coccinellidae), a predator of Bemisia argentifolii (Hom., Aleyrodidae). Journal of Applied Entomology, v.120, p.369-373, 1996. 
LOURENÇÃO, A.L.; NAGAI, H. Surtos populacionais de Bemisia tabaci no Estado de São Paulo. Bragantia, v.53, n.1, p.53-59, 1994.

LOWERY, D.T.; ISMAN, M.B. Insect growth regulating effects of neem extract and azadirachtin on aphids. Entomologia experimentalis et applicata, v.72, p.77-84, 1994.

LOWERY, D.T.; ISMAN, M.B. Toxicity of neem to natural enemies of aphids. Phytoparasitica, v.23, n.4, p.297-306, 1995.

LOWERY, D.T.; ISMAN, M.B.; BRARD, N.L. Laboratory and field evaluation of neem for the control of aphids (Homoptera: Aphididae). Journal of Economic Entomology, v.86, n.3, p.864-870, 1993.

MARANHÃO, Z. Plantas inseticidas. Revista de Agricultura, v.29, p.113-121, 1954.

MARIAPPAN, V.; SAXENA, R.C. Effect of blends of custard-apple oil and neem oil on survival of Nephotettix virescens and Tungro virus transmission. International Rice Research Newsletter, v.8, n.4, p.15-16, 1983a.

MARIAPPAN, V.; SAXENA, R.C. Effect of custard-apple oil and neem oil survival of Nephotettix virescens (Homoptera: Cicadellidae) and on rice tungro virus transmission. Journal of Economic Entomology, v.76, n.3, p.573-576, 1983b.

MARTIN, J.H. An identification guide to common whitefly pest species of the world (Homoptera: Aleyrodidae). Tropical Pest Management, v.33, n.4, p.298-322, 1987. 
McCLOSKEY, C.; ARNASON, J.T.; DONSKOV, N.; CHENIER, R.; KAMINSKI, J.; PHILOGĖNE, B.J.R. Third trophic level effects of azadirachtin. The Canadian Entomologist, v.125, p.163-165, 1993.

MCMILLIAN, W.W.; BOWMAN, M.C.; BURTON, R.L.; STARKS, K.J.; WISEMAN, B.R. Extract of chinaberry leaf as a feeding deterrent and growth retardant for larvae of the corn earworm and fall armyworm. Journal of Economic Entomology, v.62, n.3, p.708-710, 1969.

MELO, P.C.T. Mosca branca ameaça produção de hortaliças. Campinas: ASGROW do Brasil Sementes, 1992. 2p.

MIKOLAJCZAK, K.L.; REED, D.K. Extractivines of seeds of the Meliaceae: effects on Spodoptera frugiperda (J.E. Smith), Acalymma vittatum (F.), and Artemia salina Leach. Journal of Chemical Ecology, v.13, n.1, p.99-111, 1987.

MIKOLAJCZAK, K.L.; ZILKOWSKI, B.W.; BARTELT, R.J. Effect of meliaceous seed extracts on growth and survival of Spodoptera frugiperda (J.E. Smith). Journal of Chemical Ecology, v.15, n.1, p.121-128, 1989.

MORDUE (LUNTZ), A.J.; BLACKWELL, A. Azadirachtin: an update. Journal of Insect Physiology, v.39, n.11, p.903-924, 1993.

MOUND, L.A. Biology and identity of whitefly vectors of plant pathogens. In: PLUMB, R.T.; THRESH, J.M. (Ed.) Plant virus epidemiology, Oxford: Blackwell Scientific, 1983. p. 305-313.

MUNAKATA, K. Insect feeding deterrent in plants. In: SHOREY, H.H.; McKELVEY JUNIOR., J.J. (Ed.) Chemical control of insect behavior: 
theory and application. New York:John Wiley, 1977. p.95.

MURRANT, A.F.; RACCAH, B.; PIRONE, I.P. Transmission by vectors. In: MILNE, R.G . (Ed.) The plant viruses: the filamentous plant viruses. New York: Plenum Press, 1988. p.237-265.

NARDO, E.A.B. de; COSTA. A.S. Extratos de Melia azedarach e óleo vegetal reduzem disseminação no mosaico dourado do feijoeiro. Fitopatologia Brasileira, v.15, n.2, p.145, 1990.

NARDO, E.A.B. de; COSTA. A.S.; LOURENÇÃO, A.L. Melia azedarach extract as an antifeedant to Bemisa tabaci (Homoptera: Aleyrodidae). Florida Entomologist, v.80, n.1, p.92-94, 1997.

NATARAJAN, K.; SUNDARAMURTHY, V.T. Effect of neem oil on cotton whitefly (Bemisia tabaci). Indian Journal of Agricultural Sciences, v.60, n.4, p.290-291, 1990.

NISBET, A.J.; WOODFORD, J.A.T.; STRANG, R.H.C.; CONRDLY, J.D. Systemic antifeeding effects of azadirachtin on the peach-potato aphid Myzus persicae. Entomologia Experimentalis et Applicata, v.68, p.8798, 1993.

NORMAN JUNIOR, J.W.; RILEY, D.J.; STANSLY, P.A.; ELLSWORTH, P.C.; TOSCANO, N.C. Management of silverleaf whitefly: a comprehensive manual on the biology, economic impact and control tactics. Washington:USDA,CSREES, s.d. 24p.

OHNESORGE, B.; RAPP, G. Monitoring Bemisia tabaci: a review. Agriculture, Ecosystems and Environment, v.17, p.21-28, 1986. 
OSMAN, M.Z.; PORT, G.R. Systemic action of neem seed substances against Pieris brassicae. Entomologia Experimentalis et Applicata, v.54, p.297300, 1990.

PANDEY, U.K.; PANDEY, M.; CHUAHAN, S.P.S. Insecticidal properties of some plant material extracts against painted bug Bagrada cruciferarum Kirk. Indian Journal of Entomology, v.43, n.4, p.404-407, 1981.

PAULSON, G.S.; BEARDSLEY, J.W. Whitefly (Hemiptera: Aleyrodidae) egg pedicel insertion into host plant stomata. Annals of The Entomological Society of America, v.78, n.4, p.506-509, 1985.

PATEL, H.M.; JHALA, R.C.; PANDYA, H.V.; PATEL, C.B. Biology of whitefly (Bemisia tabaci) on okra (Hibiscus esculentus). Indian Journal of Agricultural Science, v.62, n.7, p.497-499, 1992.

PERRING, T.M.; COOPER, A.D.; KAZMER, D.J. Identification of the poinsettia strain of Bemisia tabaci (Homoptera: Aleyrodidae) on brocoli by electrophoresis. Journal of Economic Entomology, v.85, p.1278-1284, 1992.

PERRING, T.M.; FARRAR, C.A.; COOPER, A.D. Mating behaviour and competitive displacement in whiteflies. p.24, 1994. (ARS. Bulletin, 125).

PERRING, T.M.; COOPER, A.D.; KASMER, D.J.; SHIELDS, C.; SHIELDS, J. New strain of sweetpotato whitefly invades California vegetables. California Agriculture, v.45, p.10-12, 1991. 
PERRING, T.M.; COOPER, A.D.; RODRIGUEZ, R.J.; FARRAR, C.A.; BELLOWS JUNIOR, T.S. Identification of a whitefly species by genomic and behavioral studies. Science, v.259, p.74-77, 1993.

POLLARD D. G. Feeding habitats of the cotton whitefly, Bemisia tabaci Genn. (Homoptera: Aleyrodidae). Annals of Applied Biology, v.43, n.4, p.664671, 1955.

POWELL, D.A.; BELLOWS JUNIOR, T.S. Adult longevity, fertility and population growth rates for Bemisia tabaci (Genn.) (Hom., Aleyrodidae) on two host plant species. Journal of Applied Entomology, v.113, p.68-78, 1992.

PRABHAKER, N.; COUDRIET, D.L.; MEYERDIRK, D.E. Insecticide resistance in the sweetpotato whitefly, Bemisa tabaci (Homoptera: Aleyrodidae). Journal of Economic Entomology, v.78, n.4, p.748-752, 1985.

PRABHAKER, N.; COUDRIET, D.L.; TOSCANO, N.C. Effect of synergists on organophosphate and permethrin resistance in sweetpotato whitefly (Homoptera: Aleyrodidae). Journal of Economic Entomology, v.81, n.1, p.34-39, 1988.

PRABHAKER, N.; TOSCANO, N.C ;COUDRIET, D.L. Susceptibility of the immature and adult stages of the sweetpotato whitefly (Homoptera: Aleyrodidae) to selected inseticides. Journal of Economic Entomology, v.82, n.4, p.983-988, 1989. 
PRABHAKER, N.; TOSCANO, N.C ;COUDRIET, D.L. Comparison of neem, ureia, and amitraz as oviposition supressants and larvicides against Bemisia argentifolii (Homoptera:Aleyrodidae). Journal of Economic Entomology, v.92, n.1, p.40-46, 1999.

PURI, S.N.; BHOSLE, B.B.; ILYAS, M.; BUTLER JUNIOR., G.D.; HENNEBERRY, T.J. Detergents and plant-derived oils for control of the sweetpotato whitefly on cotton. Crop Protection, v.13, n.1, p.45-48, 1994.

REMBOLD, $\mathrm{H}$. Isomeric azadirachtins and their mode of action. In: JACOBSON, M. (Ed.) The neem tree. Boca Ratón: CRC Press, 1988. p.47-67. (Focus on Phytochemical Pesticides, 1).

RODRÍGUEZ H., C. Efeito de extratos aquosos de Meliaceae no desenvolvimento de Spodoptera frugiperda (J.E. Smith, 1797) (Lepidoptera: Noctuidae). Piracicaba, 1995. 100p. Tese (Doutorado). Escola Superior de Agricultura "Luiz de Queiroz", Universidade de São Paulo.

RODRÍGUEZ H., C.; LAGUNES T., A. Polvos vegetales y minerales; una opción de combate de insectos plaga en el almacenamiento rústico. In: SIMPOSIO NACIONAL DE ENTOMOLOGIA DE PRODUCTOS ALMACENADOS, 2, Ooxaca, 1990. Perspectivas de la investigación en México. Ooxaca:Sociedad Mexicana de Entomológia, 1990. p.13-28.

RODRÍGUEZ H., C.; VENDRAMIM, J.D. Avaliação da bioatividade de extratos aquosos de Meliaceae sobre Spodoptera frugiperda (J.E. Smith). Revista de Agricultura, v.72, n.3, p.305-318, 1997. 
RODRÍGUEZ H., C.; VENDRAMIM, J.D. Uso de indices nutricionales para medir el effecto insetistatico de extractos de Meliaceae sobre Spodoptera frugiperda. Manejo integrado de Plagas, v.48, p.11-18, 1998.

ROEL, A.R. Efeito de extratos orgânicos de Trichilia pallida Swartz (Meliaceae) na sobrevivência e desenvolvimento de Spodoptera frugiperda (J.E. Smith, 1797) (Lepidoptera: Noctuidae). Piracicaba, 1998. 115p. Tese (Doutorado). Escola Superior de Agricultura "Luiz de Queiroz", Universidade de São Paulo.

ROEL, A.R.; VENDRAMIM, J.D.; FRIGHETTO, R.T.S.; FRIGHETTO, N. Toxic activity of organic extracts from Trichilia pallida Swartz (Meliaceae) against Spodoptera frugiperda (J.E. Smith). Anais da Sociedade Entomológica do Brasil, v.29, n.4, p.799-808, 2000.

SABILLON, A.; BUSTAMANTE, M. Evaluación de extractos botánicos para el control de plagas del tomate (Lycopersicon esculentum Mill.). CEIBA, v.36, n.2, p.179-187, 1995.

SAXENA, R.C.; BONCODIN, M.E.M. Effect of neem seed bitters (NSB) on green leafhopper (GLH) feeding. International Rice Research Newstetter, v.13, n.1, p.27, 1988a.

SAXENA, R.C.; BONCODIN, M.E.M. Effect of neem seed bitters (NSB) on green leafhopper (GLH) survival and rice tungro virus (RTV) transmission. International Rice Research Newstetter, v.13, n.1, p.25-26, $1988 \mathrm{~b}$.

SAXENA, R.C.; KHAN, Z.R. Electronically recorded disturbances in feeding 
behavior of Nephotettix virescens (Homoptera: Cicadellidae) on neem oiltreated rice plants. Journal of Economic Entomology, v.78, n.1, p.222$226,1985 a$.

SAXENA, R.C.; KHAN, Z.R. Effect of neem oil on survival of Nilaparvata lugens (Homoptera: Delphacidae) and on grassy stunt and ragged stunt virus transmission. Journal of Economic Entomology, v.78, n.3, p.647-651, $1985 b$.

SAXENA, R.C.; ZHANG, Z.T.; BONCODIN, M.E.M. Neem oil affects courtship signals and mating behavior of brown planthopper Nilaparvata lugens (Stal) (Hom., Delphacidae) females. Journal of Applied Entomology, v.116, p.127-132, 1993.

SCHMUTTERER, H. Potential of Azadirachtin-containing pesticides for integrated pest control in developing and industrialized countries. Journal of Insect Physiology, v.34, n.7, p.713-719, 1988.

SCHMUTTERER, $H$. Properties and potential of natural pesticides from the neem tree, Azadirachta indica. Annual Review of Entomology, v.35, p.271-297, 1990.

SCHOONHOVEN, L.M.; DERKSEN-KOPPERS, I. Effects of some allelochemics on food uptake and survival of a polyphagous aphid, Myzus persicae. Entomologia Experimentalis et Applicata, v.19, p.52-56, 1976.

SCHUSTER, D.J.; MUELLER, T.F.; KRING, J.B.; PRICE, J.F. Relationship of 
the sweetpotato whitefly with a silverleaf disorder of squash. Hortscience, v.25, p.1618-1620, 1990.

SINGH, R.P.; DEVAKUMAR, C.; DHINGRA, S. Activity of neem (Azadirachta indica A. Juss) seed kernel extracts against the mustard aphid, Lipaphis erysimi. Phytoparasitica, v.16, n.3, p.225-230, 1988.

SKINNER, R.H. Leaf temperature effects on Bemisia argentifolii (Homoptera: Aleyrodidae) oviposition. Environmental Entomology, v.25, n.6, p.1371$1375,1996 a$.

SKINNER, R.H. Response of Bemisia argentifolii (Homoptera:Aleyrodidae) to water and nutrient stressed cotton. Environmental Entomology, v.25, n.2, p.401-406, 1996b.

SOON, L.G.; BOTTRELL, D.G. Neem pesticides in rice: potential and limitations, Manila: IRRI, 1994. 64 p.

STANSLY, P.A.; LIU, T.X. Selectivity of insecticides to Encarsia pergandiella (Hymenoptera: Aphelinidae) an endoparasitoid of Bemisia argentifolii (Hemiptera: Aleyrodidae). Bulletin of the Entomological Research, v.87, p.525, 531, 1997.

SUBRAHMANYAM, B. Azadirachtin, a naturally ocurring insect growth regulator. Proceedings of the Indian Academic of Sciences, v.99, n.3, p.277-288, 1990.

THOMAZINI, A.P.B.W. Efeito de genótipos de Lycopersicon spp. e de extratos aquosos de Trichilia pallida Swartz (Meliaceae) sobre Tuta absoluta (Meyrick, 1917) (Lep., Gelechiidae). Piracicaba, 1999. 95 p. Tese 
(Doutorado). Escola Superior de Agricultura "Luiz de Queiroz", Universidade de São Paulo.

TORRECILLAS, S.M. Efeito de extratos aquosos de Trichilia pallida Swartz (Meliaceae) no desenvolvimento de Spodoptera frugiperda (J.E.Smith, 1797) (Lepidoptera) em diferentes genótipos de milho. Piracicaba, 1997. 141p. Dissertação (Mestrado). Escola Superior de Agricultura "Luiz de Queiroz", Universidade de São Paulo.

TSAI, J.H.; WANG, K. Development and reproduction of Bemisia argentifolii (Homoptera: Aleyrodidae) on five host plants. Environmental Entomology, v.25, n.4, p.810-816, 1996.

VAN LENTEREN, J.C.; NOLDUS, L.P.J.J. Whitefly-plant relationships: behavioural and ecological aspects. In: GERLING, D. (Ed.) Whitefies: their bionomics, pest status and management. Andover:Intercept, 1990. cap.3, p.47-89.

VÁZQUEZ, L.L.; JIMÉNEZ, R.; IGLESIA, M. DE LA; MATEO, A.; BORGES, M. Plantas hospederas de Bemisia tabaci (Homoptera: Aleyrodidae) en Cuba. Revista de Biologia Tropical, v.45, n.1, p.143-148, 1997.

VENDRAMIM, J.D. Uso de plantas inseticidas no controle de pragas. In: Ciclo de Palestras sobre Agricultura Orgânica, 2., Campinas, 1997. Fundação Cargill, p.64-69. 
VENDRAMIM, J.D.; SCAMPINI, P.J. Efeito do extrato aquoso de Melia azedarach sobre o desenvolvimento de Spodoptera frugiperda (J.E. Smith) em dois genótipos de milho. Revista de Agricultura, v.72, n.2, p.159-170, 1997.

VILLAS BÔAS, G.L.; FRANÇA, F.H.; ÁVILA, A.C.; BEZERRA, I.C. Manejo Integrado da mosca-branca Bemisia argentifolii. Brasília: CNP, 1997. 12 p. (Embrapa. CNP Hortaliças. Circular Técnica, 9).

WAGNER, T.L. Temperature-dependent development, mortality, and adult size of sweetpotato whitefly biotype B (Homoptera: Aleyrodidae) on cotton. Environmental Entomology, v.24, n.5, p.1179-1188, 1995.

WALKER, G.P.; GORDH, G. The occurrence of apical labial sensila in the Aleyrodidae and evidence for a contact chemosensory function. Entomologia Experimentalis et Applicata, v.51, p.215-222, 1989.

WANG, K.; TSAI, J.H. Temperature effect on development and reproduction of silverleaf whitefly (Homoptera: Aleyrodidae). Annals of Entomological Society of America, v.89, n.3, p.375-384, 1996.

WARTHEN JUNIOR., J.D. Azadirachta indica: a source of insect feeding inhibitors and growth regulators. Agricultural Reviews and Manual RMNE-4, U.S. Departament of Beltsville, MD. 1979, 21 p.

WARTHEN JUNIOR., J.D. Neem (Azadirachta indica A. Juss): organisms affected and reference list update. Proceedings of the Entomological Society of Wahshington, v.91, n.3, p.367-368, 1989. 
WEST, A.J.; MORDUE (LUNTZ), A.J. The influence of azadirachtin of the feeding behaviour of cereal aphids and slugs. Entomologia Experimentalis et Applicata, v.62, p.75-79, 1992.

WISOKI, M. Problems and trends of agricultural entomology at end the 2nd millenium. Bolletin do Laboratório di Entomologia Agricola Filippo Silvestri, v.54, p.89-143, 1998.

WOOL, D.; CALVERT, L.; CONSTANTINO, L.M.; BELLOTTI, A.C.; GERLING, D. Differentiation of Bemisia tabaci (Genn) (Homoptera: Aleyrodidae) populations in Colombia. Journal of Applied Entomology, v.117, p.122134, 1994.

XIE, Y.S.; ISMAN, M.B.; GUNNING, P.; MACKINNON, S.; ARNASON, J.T.; TAYLOR, D.R.; SÁNCHEZ, P.; HASBUN, C.; TOWERS, G.H.N. Biological activity of extracts of Trichilia species and the limonoid hirtin against lepidopteran larvae. Biochemical Systematics and Ecology, v.22, n.2, p.129-136, 1994.

YEE, W.L.; TOSCANO, N.C. Ovipositional preference and development of Bemisia argentifolii (Homoptera: Aleyrodidae) in relation to alfafa. Journal of Economic Entomology, v.89, n.4, p.870-876, 1996.

YOKOMI, R.K.; HOELMER, K.A.; OSBORNE, L.S. Relationships between the sweetpotato whitefly and the squash silverleaf disorder. Phytopathology, v.80, p.895-900, 1990. 
YOSHIDA, H.A.; TOSCANO, N.C. Comparative effects of selected natural insecticides on Heliothis virescens (Lepidoptera: Noctuidae) larvae. Journal of Economic Entomology, v. 87, n.2, p.305-310, 1994.

ZUCCHI, R.A.; SILVEIRA NETO, S.; NAKANO, O. Guia de identificação de pragas agrícolas. Piracicaba: FEALQ, 1993. $139 \mathrm{p}$. 